\title{
Growing up in Pakistan: The separate experiences of males and females
}

Cynthia B. Lloyd

Population Council

Monica J. Grant

Population Council

Follow this and additional works at: https://knowledgecommons.popcouncil.org/departments_sbsr-pgy

Part of the Demography, Population, and Ecology Commons, Family, Life Course, and Society Commons, Gender Equity in Education Commons, and the International Public Health Commons How does access to this work benefit you? Let us know!

\section{Recommended Citation}

Lloyd, Cynthia B. and Monica J. Grant. 2004. "Growing up in Pakistan: The separate experiences of males and females," Policy Research Division Working Paper no. 188. New York: Population Council. Version of record: https://www.nap.edu/read/11524/chapter/10 


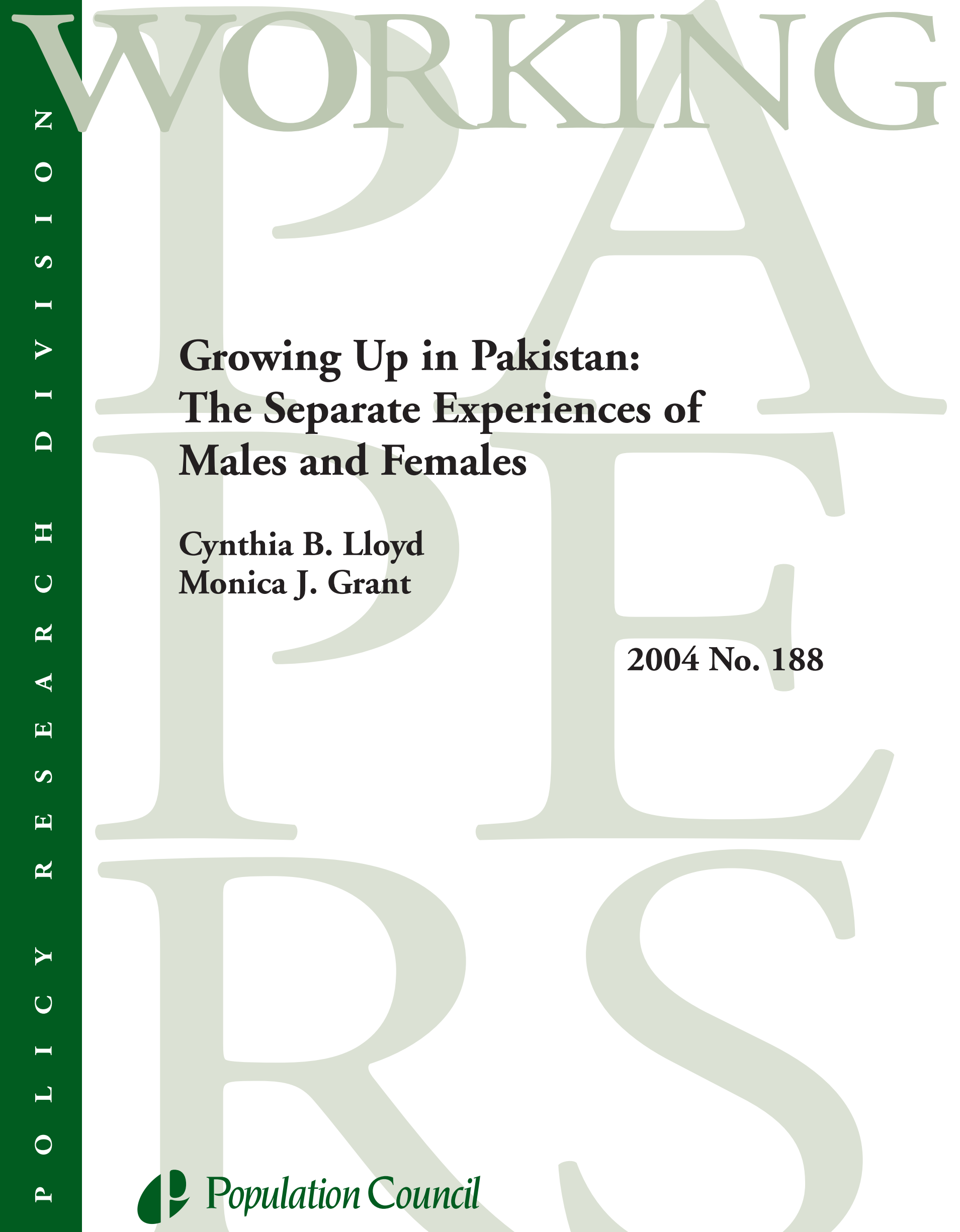




\title{
Growing Up in Pakistan: \\ The Separate Experiences of Males and Females
}

\author{
Cynthia B. Lloyd \\ Monica J. Grant
}

Cynthia B. Lloyd is Director, Social Science Research, and Monica J. Grant is Research Coordinator, Policy Research Division, Population Council.

Acknowledgments: The approach taken in this paper has drawn on discussions with members of the NAS Panel on Transitions to Adulthood in Developing Countries. The authors acknowledge helpful comments from Judith Diers, Zeba Sathar, and two anonymous reviewers. They also acknowledge the generous support of the Rockefeller Foundation, the Department for International Development, UNICEF, and UNFPA.

This material may not be reproduced without written permission from the authors. For a list of Policy Research Division Working Papers, including those available for downloading in PDF format, see www.popcouncil.org/publications/wp/prd/rdwplist.html.

(C) 2004 The Population Council, Inc. 


\begin{abstract}
This paper examines gender differences in transitions to adulthood in Pakistan. The analysis is based on data from the 2001-02 Adolescent and Youth Survey of Pakistan (AYSP), a nationally representative survey of young people aged 15-24 undertaken by the Population Council's Islamabad office. The survey covers key aspects of adolescents' lives, including the timing of several adult transitions and a detailed accounting of time use over the previous 24 hours. The results of the analysis confirm the fundamental importance of schooling to transitions to adulthood. Those without any schooling, which still include 15 percent of young men and 46 percent of young women, assume the work burdens of adults prematurely and are deprived of the opportunity for learning in an institutional setting outside the family. Those who do attend school eventually take up gender-stereotyped roles; however, they do so with some delay, allowing them to experience a longer transition to adulthood. For both males and females, there appears to be a large lag in years between the assumption of adult work roles, whether in the domestic setting or in the labor market, and the assumption of adult family roles as marked by the timing of first marriage. Recent further delays in the timing of first marriage for young women have been accompanied by a rise in the percent working for pay during the later adolescent years; a similar trend is not apparent for young men. A multivariate analysis of some of the factors associated with variations in daily work hours among young people demonstrates the potential for change created by opportunities for higher levels of schooling, vocational training, and formal-sector jobs. The nature of current opportunities available to young people, however, appears to reinforce traditional gender role stereotypes.
\end{abstract}


In most parts of the developing world, adolescents and young adults face rapidly improving prospects for their future, as a result of economic development, modernization, and globalization. These changes have resulted in large increases in school participation and educational attainment among the young, which in turn have been associated with declines in child labor and delays in marriage and childbearing. Some of these changes are occurring as part of the natural process of development; others are occurring in response to the pressures and opportunities of the external environment that are affecting the economic, political, and cultural climate.

In Pakistan, however, primary school enrollment rates still fall far short of universal and have shown no improvement for males in the 1990s and only limited improvement for females from a relatively low base (Pakistan Federal Bureau of Statistics 1998). As in much of the rest of the developing world, the age at marriage in Pakistan is rising for both males and females (Mensch, Singh, and Casterline 2003). Nonetheless, many adolescents, particularly females, continue to marry below the age of 18 despite the fact that the legal age for both sexes in Pakistan is 18. Furthermore, work among children under age 15 remains relatively common.

This paper describes the transitions to adulthood of females and males in Pakistan, highlighting the implications of formal schooling for the timing and content of these transitions. Our analysis is based on the 2001/02 Adolescent and Youth Survey of Pakistan, a nationally representative survey of young people aged 15-24 covering the key aspects of adolescents' lives, including the timing of specific transitions and a detailed accounting of time use (Sathar et al. 2003). The paper begins with a brief review of pertinent literature and an introduction to the data. The results of the analysis are presented in two main sections. The first characterizes transitions to adulthood in terms of timing, sequencing, and duration. Here, we concentrate on three relatively easy-tomeasure transitions in particular: the transition to paid work, the transition to marriage, and the departure from the natal home. The second section explores the transition to work in more depth with time-use data on all types of work including unpaid economic work and noneconomic household work. Because many young people in Pakistan, particularly females, assume adult work roles without entering the paid labor force, the transition to work is difficult to capture using conventional labor force data. A particular interest of this paper is to map changes in social and economic mobility by age and to define the role of formal schooling in providing opportunities for mobility both directly and indirectly.

\section{LITERATURE REVIEW}

The developmental phase between childhood and adulthood is often labeled adolescence. This lifecycle phase, common to all societies, involves the acquisition of human and social capital, the consolidation of personal identity, and the emergence of a sense of personal efficacy (Mensch et al. 1998). It is a phase of life during which young people have many first-time experiences, including travel or residence away from home, paid work, sex, military service, unemployment, engagement, marriage, and birth. It is also a time during which young people emerge from dependency on their parents and 
other family members and acquire a growing scope for agency in their lives. Adolescence is now recognized in the International Convention on the Rights of the Child (ICRC) as a phase of "evolving capacities" requiring a balance of societal and familial protections, respect for rights, and opportunity for voice (United Nations General Assembly 1990).

While the ICRC defines legal adulthood as occurring by age 18, the developmental aspects of this phase of the life cycle may continue past the teens and into the early to mid 20s. The social roles associated with adulthood include worker, spouse, parent, and household manager. By a certain age, society recognizes everyone as an adult, whether or not they have acquired any of these roles. If one or more of these roles is assumed during the teens, however, this does not necessarily mean that adulthood has been fully achieved if certain developmental tasks are not yet complete or if young people themselves have not had an opportunity to play a role in the decisionmaking process. Indeed, this shift in the locus of decisionmaking over the course of the transition challenges current approaches to household allocation models, which tend to assume that married people regardless of age are decisionmakers while unmarried young people who do not head their own households are not.

For the first part of the paper, we build on an earlier U.S. literature that traces key transitions during adolescence and young adulthood, including exit from school, entrance into the labor market, and first marriage as well as various indicators of mobility. Winsborough (1978) focused on trends over 30 years in the timing and duration of four transitions for young American males: exit from school, entrance into the labor market, entrance into the military, and first marriage. For each transition, he measured the age at which 25 percent, 50 percent, and 75 percent of each age cohort had made each transition and measured the duration of the transition as the mean years elapsed between the age at which the first 25 percent completed the transition and the age at which the first 75 percent completed the transition. He found a trend toward a later start to the transition but at the same time a shortening of the duration of the transition both within and across categories. $^{1}$

Rindfuss (1991), using both cross-sectional and longitudinal data, explored transitions during the "young adult years" from ages 18 to 30 for males and females. He observed that this phase of life is "dense" in demographic events but with the possibility of much variability according to background characteristics such as sex, ethnicity, and socioeconomic status. Such demographic events could include, in addition to those analyzed by Winsborough, residential mobility and migration, unemployment, first sex, pregnancy, abortion, childbirth, and marital disruption. Further, Rindfuss pointed out that "the density of events during the young adult years would be even more dramatic during periods of rapid social change because young adults typically are the engines of social change" (p. 499). Rindfuss provided a valuable perspective for thinking about transitions to adulthood in developing countries, where young people are often the first generation to go to school or progress far in school and the first to have opportunities for migration and formal-sector jobs. Rapid globalization requires rapid adaptation. Young people, if given the opportunity, are likely to be the first to respond by staying longer in school, migrating 
in search of jobs, finding better pay, and delaying marriage and childbearing. Rapid economic and social change can also challenge existing gender roles, including traditional pathways to adulthood.

There has been little opportunity to study transitions to adulthood in developing countries given the lack of longitudinal data on adolescents or retrospective life-event calendars covering the adolescent years. Owing to the rapidity of change across cohorts in the experience of the transition, it is inappropriate to use current age comparisons to simulate the transition (as done, e.g., by Filgueira et al. 2001) or to rely on retrospective data from samples that are restricted to married couples. ${ }^{2}$ We are aware of a series of six surveys in Asia focusing on the transitions to adulthood among all young people aged 15-24, and three of these - for Hong Kong (1986), Thailand (1994), and Nepal (2000) have included questions on the timing of school exit, entry to work, and marriage and childbearing (Xenos 1999). To our knowledge, however, a full treatment using all the key elements of the transitions to adulthood has not yet been published.

We highlight two recent studies that have taken advantage of specially designed longitudinal data (Florez and Hogan 1990 for Colombia) and of retrospective data on the timing of events (Echarri Canovas and Amador 2001 for Mexico) in order to provide a context for the current study. Using longitudinal rural and urban surveys in Colombia to capture changes in the lives of young females aged 12 to 25 over the course of the demographic transition, Florez and Hogan describe the average number of person-years in each of five domains - school, wage work, plot work, living with husband, and living with children - and describe the diversity of combinations of activities. A key finding of their study was the increase in the time spent during these years in school or paid work relative to the past.

Echarri Canovas and Amador capture transitions for a group of young people aged 12-29 in Mexico using a national youth survey fielded in 2000 that covered the timing retrospectively of school leaving, first work, home leaving, first union, and entry into parenthood. They found that work is likely to be the first transition, often predating school exit. Some 40 percent of both males and females took their first job before age 15 . As a result, they conclude that job entry is often imposed by family circumstances at a premature age rather than freely chosen and, as such, cannot necessarily be considered a marker of adult status.

In settings where schooling is not yet universal and where work is largely informal, life-cycle transitions may lack the precision associated with publicly recognized social statuses such as student and employee, making identification and measurement much more difficult. In such circumstances, much of the lives of young people remains invisible and unmeasured, particularly transitions to adulthood that involve the assumption of new roles, changes in the location of domestic and unpaid work, and changes in the time associated with work. Durrant (2000) provides a stark example of this problem using data from the 1991 living standards measurement survey in Pakistan, which show that 45 percent of females aged 10-19 are apparently doing "nothing." In such settings, time-use data can provide an additional perspective on the association between age and all types of work. 
In light of these circumstances, in the second part of the paper we build on a literature exploring time use in the context of development-not just time spent in economic activity but also time spent on noneconomic household work. While there is a rich literature on the determinants of child labor and schooling, little attention in the adolescent literature is devoted to other types of work, including unpaid work and domestic chores, which are less well measured in most surveys (for notable exceptions see Levison and Moe 1998; Levison, Moe, and Knaul 2001). Larson and Verma (1999) reviewed data on the time use of school-aged children (5-18) from around the world and categorized time-use patterns according to country context into (1) nonindustrial unschooled, (2) transitional, and (3) postindustrial schooled populations. They find that in nonindustrial populations where most children and adolescents do not attend school, time in housework is considerable, starting at an early age, with girls by early adolescence often spending as much time on housework as adult females. By contrast, in postindustrial schooled populations, household work rarely exceeds one hour per day. Furthermore, their review of the literature suggests that girls spend significantly more time than boys on noneconomic domestic work, with their tasks more likely to be confined within the home. Among the unschooled, work for pay is particularly common for boys from poor families.

An increasing number of studies on household resource allocation, work participation, and agricultural production in developing countries include time-use data (e.g., Brown and Haddad 1995 with data for seven countries), but it is rare to find attention devoted to the changing patterns of time use by age and gender during the transition to adulthood. While the literature suggests that a gender disparity in time use emerges early in childhood (Mensch et al. 1998; Larson and Verma 1999), rising enrollment rates and later ages of school leaving are likely to delay the social enforcement of these gender differences. A much more egalitarian pattern of time use is found among males and females who remain in school than among those that have left school (Ajayi et al. 1997; Arends-Kuenning and Amin 2004). As a result, it is likely that the circumstances of current transitions to adulthood in terms of time allocation are shifting rapidly in developing countries as the proportion of time allocated to school attendance and school work increases - a trend that aggregated data are unlikely to reveal. For example, none of the data summarized by Larson and Verma (1999) are broken down by enrollment status.

\section{DATA}

The nationally representative Adolescent and Youth Survey in Pakistan (AYSP) was conducted by the Population Council and fielded from October 2001 to March 2002. The sample, drawn in collaboration with the Federal Bureau of Statistics, is based on the sampling frame from the 1998 census. Using a two-step stratified sampling procedure, 254 primary sampling units (PSUs) were selected, with urban PSUs being overrepresented. Within each PSU, households were chosen at random after a preliminary listing. In each chosen household, a parent or knowledgeable informant was interviewed, as were all resident young people in the eligible age ranges of 15 to 24 
years. A total of 6,812 household questionnaires were completed and 8,069 young people were interviewed. The questionnaires for young people included information on family background and personal characteristics, life-event histories and time-use profiles, detailed data on each transition, and information on decisionmaking, mobility, and gender role attitudes. Data on community infrastructure and facilities were also collected.

The life-event calendar asked each respondent to trace his or her life story, locating key changes in status related to school enrollment, grade, work status, residential location, living arrangements, marriage and engagement, and childbearing in relationship to each other and in calendar time going back to the age of five. The component of the life-event calendar focusing on work experience was intended to ascertain the timing of both unpaid and paid work; but, given that many young people engage in multiple activities, some paid and others unpaid, we found that only paid work was recorded on the calendar. Thus, we use these data to identify the first entry into paid work and turn to the time-use profile for a more complete picture of work roles over the course of the transition.

The time-use component of the questionnaire collected data on the activities of each respondent in the previous 24 hours or, if currently enrolled, the most recent school day. Data were recorded in hourly increments from 6AM to midnight. Multiple activities could be recorded in each hour and, when that occurred, time was divided evenly by the number of activities reported. The grid is organized into 19 discrete activities grouped into categories: personal activities, school-related activities, domestic duties, work (both paid and unpaid), leisure/spare time activities, religious activities, in transit, and other activities.

Despite repeated attempts to interview all eligible adolescents while the field teams were on location, not all eligible young people were successfully interviewed. In the overwhelming majority of cases, the reason for the nonresponse was that adolescents could not be found in the home or nearby. Sixty-six percent of eligible males were successfully interviewed and 83 percent of females. Using data collected from knowledgeable informants in the households, we can compare interviewed and noninterviewed adolescents according to a few characteristics, including age, educational attainment, marital status, and household economic status (see Table 1). For both young men and young women, those who were not interviewed were slightly older than those who were. Other significant differences are apparent for males but not females. Males who were not interviewed have on average about a year less schooling than males who were interviewed, indicating that the survey underrepresented the less educated. On the other hand, a slightly higher proportion of young males who were not interviewed came from the richest quartile. ${ }^{3}$ 
Table 1 Characteristics of interviewed and noninterviewed young people

\begin{tabular}{lccccc}
\hline & \multicolumn{2}{c}{ Males } & & \multicolumn{2}{c}{ Females } \\
\cline { 2 - 3 } \cline { 5 - 6 } & $\begin{array}{c}\text { Not } \\
\text { Interviewed }\end{array}$ & Interviewed & $\begin{array}{c}\text { Not } \\
\text { Interviewed }\end{array}$ & Interviewed \\
\hline Mean Age & $19.3^{* *}$ & $18.9^{* *}$ & & $19.2^{*}$ & $19.1^{*}$ \\
Ever Married (\%) & 17.3 & 14.3 & & 40.6 & 40.2 \\
Mean Grades Completed & $5.16^{* *}$ & $6.22^{* *}$ & & 3.49 & 3.46 \\
Poorest Quartile (\%) & 20.4 & 21.4 & & 19.1 & 23.0 \\
Richest Quartile (\%) & $23.3^{*}$ & $29.3^{*}$ & & 23.4 & 26.1 \\
& & & & \\
$\mathrm{~N}$ & 1697 & 3328 & & 1006 & 4741 \\
\hline
\end{tabular}

Source: 2001/02 AYSP

Note: * Statistically significant at $5 \%$ level

** Statistically significant at $1 \%$ level

Because our analysis focuses on the relationship between school enrollment and subsequent life-course transitions, we briefly examine patterns of enrollment and grade attainment within our sample as reported by the young people (see Table 2). These estimates are weighted to adjust for the overrepresentation of urban PSUs in the sample. Looking at the youngest cohort first (ages 15-19), we see that a slight majority of females have ever attended school (54\%) while the overwhelming majority of boys have attended $(85 \%)$. There has been some improvement in enrollment relative to the older cohort (ages 20-24) - particularly for females, whose enrollment rates have risen over the past five years by 7 percentage points. Owing to dropout during the primary years, these percentages are not maintained through primary completion. For the younger cohort, 40 percent of females and 70 percent of males complete primary school. There has been a slight improvement for females and no change for males in the last five years.

\section{The Timing, Sequencing, and Duration of Transitions to Adulthood}

To characterize gender differences at various stages of the transition to adulthood, we divide adolescence and young adulthood into three phases: (1) early, ages 10-14; (2) middle, ages 15-19; and (3) late, ages 20-24. While transitions may continue past the age of 24, we are constrained by our data to focus on persons under age 25. During the early phase of the transition, most young people in Pakistan experience puberty (Sathar et al. 2003), and many of those who start school complete their primary education. Work under the age of 15 is defined as child labor by various international labor conventions as well as by the International Convention on the Rights of the Child (ICRC), and many countries, including Pakistan, have agreed to take steps to eliminate it. Thus economic work during this phase of life is discouraged and seen as jeopardizing schooling. During the middle phase of the transition, which encompasses the last phase of childhood as defined by ICRC (when certain kinds of hazardous work continue to be discouraged and marriage is not yet legal in Pakistan) and the first few years after assuming the legal age of majority, young people begin to take up adult roles including paid work, marriage, and 
departure from home. The last phase of the transition covered by our data captures further movement into the work place and out of the natal home, steps usually linked to marriage for young women and often linked to work for young men. ${ }^{4}$

Table 2 School enrollment and primary school attainment by age and sex

\begin{tabular}{ccc}
\hline & Percent ever enrolled & $\begin{array}{c}\text { Percent completing } \\
\text { primary }\end{array}$ \\
\hline $15-19$ & 85 & \\
Male & 54 & 70 \\
Female & & 40 \\
$20-24$ & 82 & 69 \\
Male & 47 & 36 \\
Female & & \\
\hline
\end{tabular}

Source: 2001/02 AYSP

Figures 1 and 2 compare, for females and males respectively, the different transitions experienced by those who have never attended school and those who have ever attended. They are based on a life table analysis and depict transitions to first paid work, marriage, and leaving home starting at age 5 and ending at age 24 . We are unable to look at timing of first work more broadly, including unpaid work, because little unpaid work was reported in the life-event calendar despite efforts to define work broadly. Each figure is derived from the data collected in the life-event calendar and depicted according to the three phases described above. ${ }^{5}$

Looking first at Figure 1, almost no females who ever entered school marry or leave home before age 15, and no more than 10 percent start paid work during this first phase of the transition. By contrast, slightly less than 30 percent of females who have never been to school have entered paid work before reaching age 15, and slightly less than 20 percent have married and left home. For females who never attended school (Figure 1a), the transition to paid work flattens out during the middle phase of the transition and rises slowly to over 40 percent by age 25 . The percent of females who have ever worked for pay rises sharply among those who have ever attended school, ending up by age 25 at levels similar to those achieved by young females who never attended school. The transition to marriage, which coincides precisely with departure from home among females who never attended school, accelerates rapidly during the middle phase of the transition, and by age 20 more than 60 percent are married. By contrast, the percent married among those who have ever been to school (Figure 1b) is only slightly above 20 percent by the age of 20 , with a few leaving home before marriage. Also notable is a huge gap - roughly eight to nine years - between the age of school exit and the age of marriage for those who ever attended school.

Figure 2 depicts the same comparisons for young males. Among the minority of males who never attended school, 60 percent have entered paid work before age 15, with 30 percent having done so by age 10 (Figure 2a). Very few males leave home during this first phase of the life-cycle transition. Marriage rates begin to rise during the middle 
phase of the transition, but reach only a little under 60 percent by our final point of observation. By contrast, entry into first paid work appears to be closely tied to school leaving among those who ever attend school, thus holding the prevalence of first work to about 25 percent by age 15, a rate that is still very high by international standards (Figure $2 b$ ). Few males leave home regardless of whether or not they ever attend school, and marriage among male schoolgoers is delayed much longer relative to those who never attended. About 35 percent of all males in our sample have married by age 25 . Thus, for the majority there is a large gap of eight to ten years between entry into work and marriage.

We also explore the possibility of changes in the timing of the early and middle phases of the transitions within the last five years by comparing the experience of our two age cohorts (15-19 and 20-24). Because we found no evidence of changes in any of these transitions for young males, we present only the results for young females. Figures $3 \mathrm{a}$ and $3 \mathrm{~b}$ show changes in the transition to first paid work and school exit (for those who ever attended school). For both categories of young females, we found evidence that the percent of females taking up paid work during the middle phase of the transition is greater among the younger cohort, and in both cases these changes are statistically significant. ${ }^{6}$ Among those who ever attended school, the rising prevalence of work is apparent even at earlier ages. We also see a hint of slightly higher dropout rates among females who have some schooling, perhaps in response to changes in job opportunities for those with some education.

Recent changes in transitions to marriage and home leaving during the early and middle phases of the transition are depicted in Figure $4 \mathrm{a}$ and $\mathrm{b}$. Whether or not females have ever attended school, there appears to be a tendency toward later ages of marriage and home leaving during the middle phase of the transition among the younger cohort. While leaving home and marrying for females tend to track very closely together, we can see the beginnings of a separation between the two events in the younger cohort of females who have attended school, with some leaving home before getting married. This may be linked to the rapid rise in entry into paid work during this phase of the transition among the same cohort. 
Figure 1 Comparison of transitions to adulthood, females

(a) Never attended school

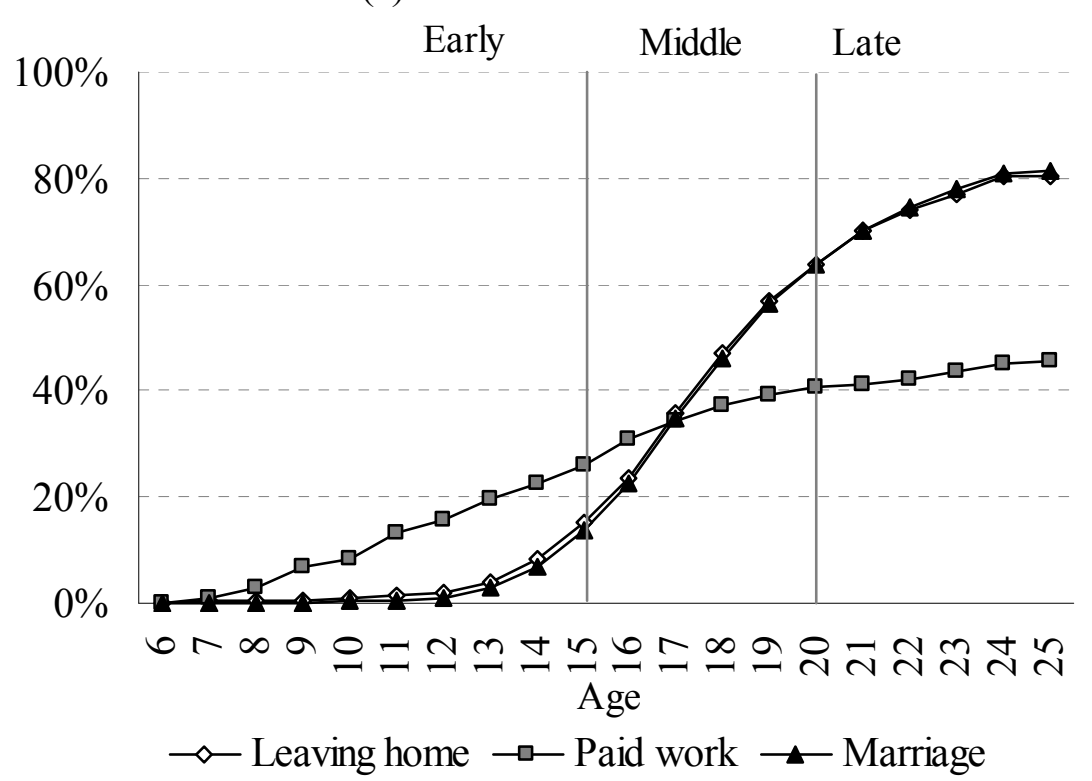

(b) Ever attended school

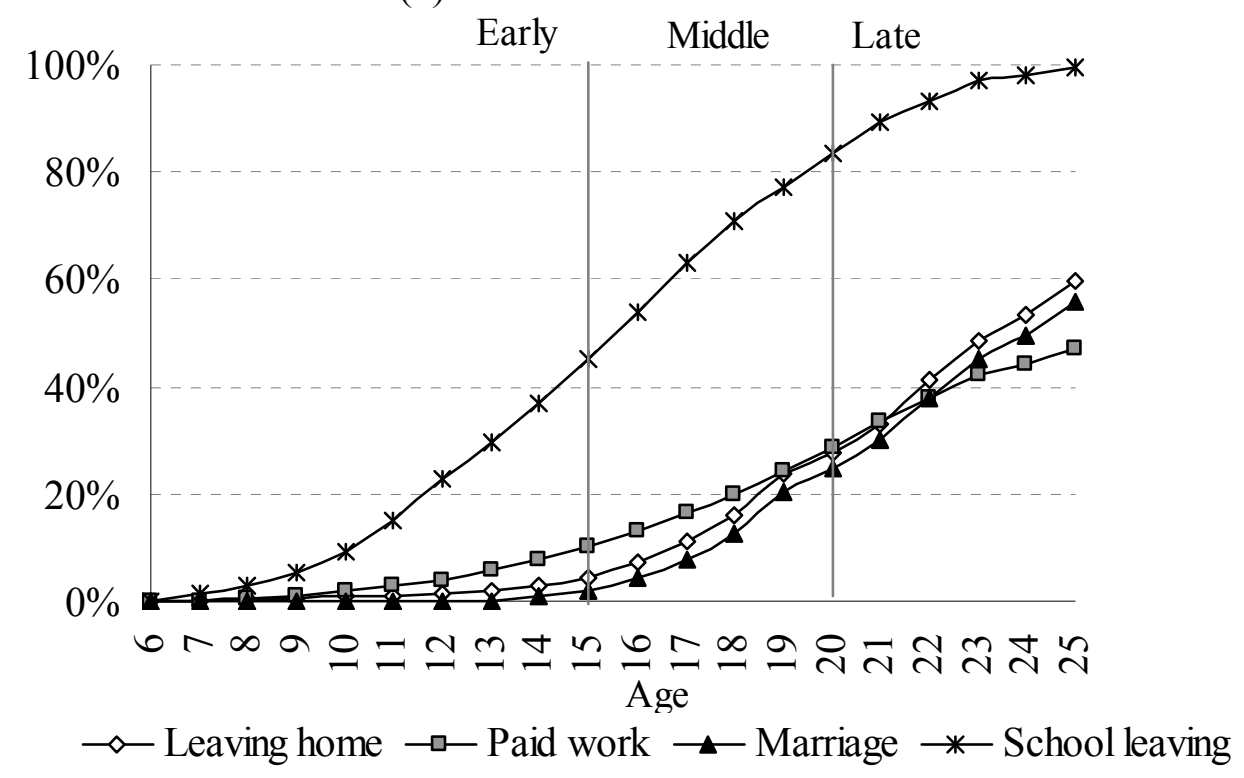

Source: 2001/02 AYSP 
Figure 2 Comparison of transitions to adulthood, males

(a) Never attended school

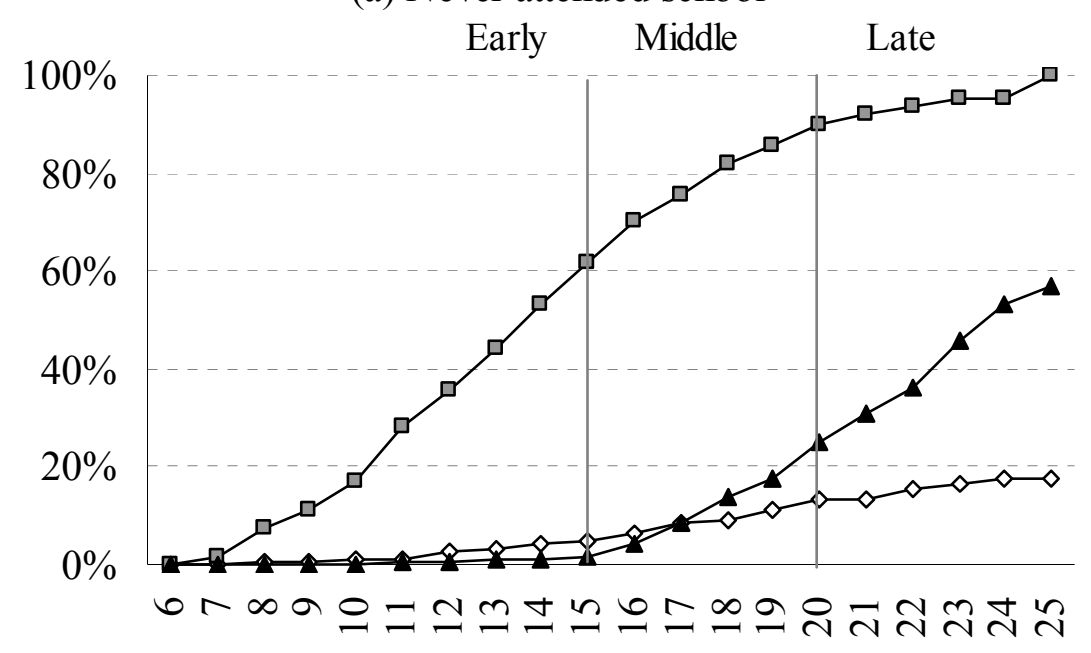

Age

$\multimap$ Leaving home $\rightarrow-$ Paid work $\multimap$ Marriage

(b) Ever attended school

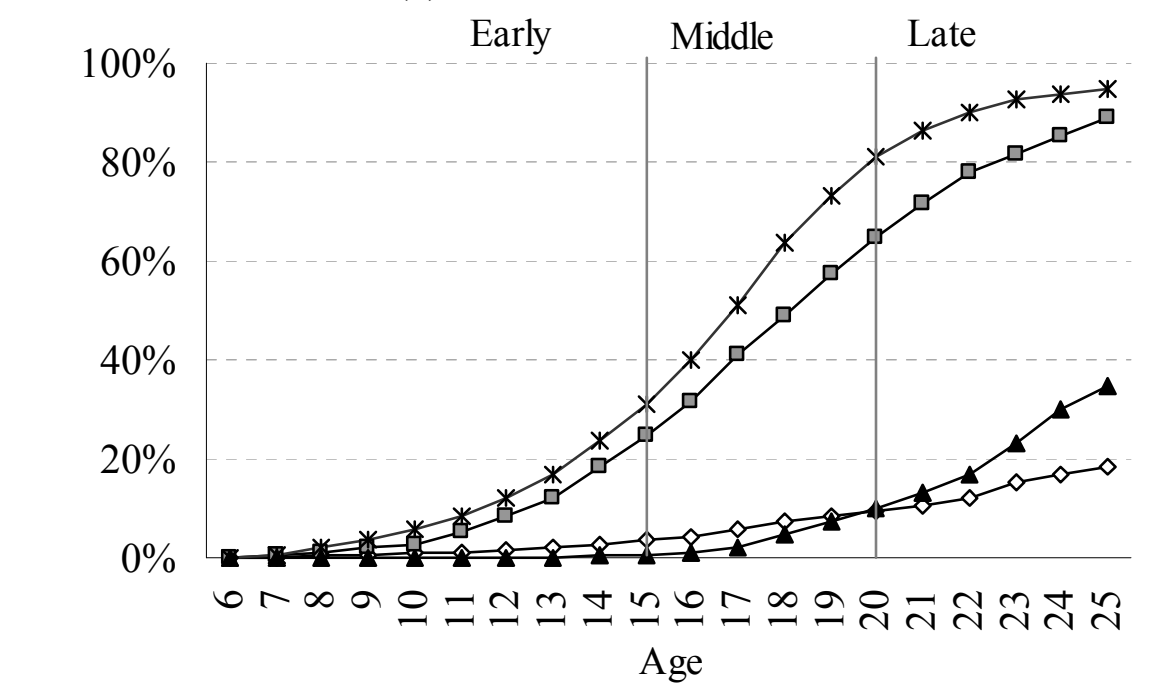

$\leadsto$ Leaving home $\rightarrow-$ Paid work $\multimap$ Marriage $\rightarrow$ School leaving 
Figure 3 Changes in school and work transitions, females

(a) Never attended school

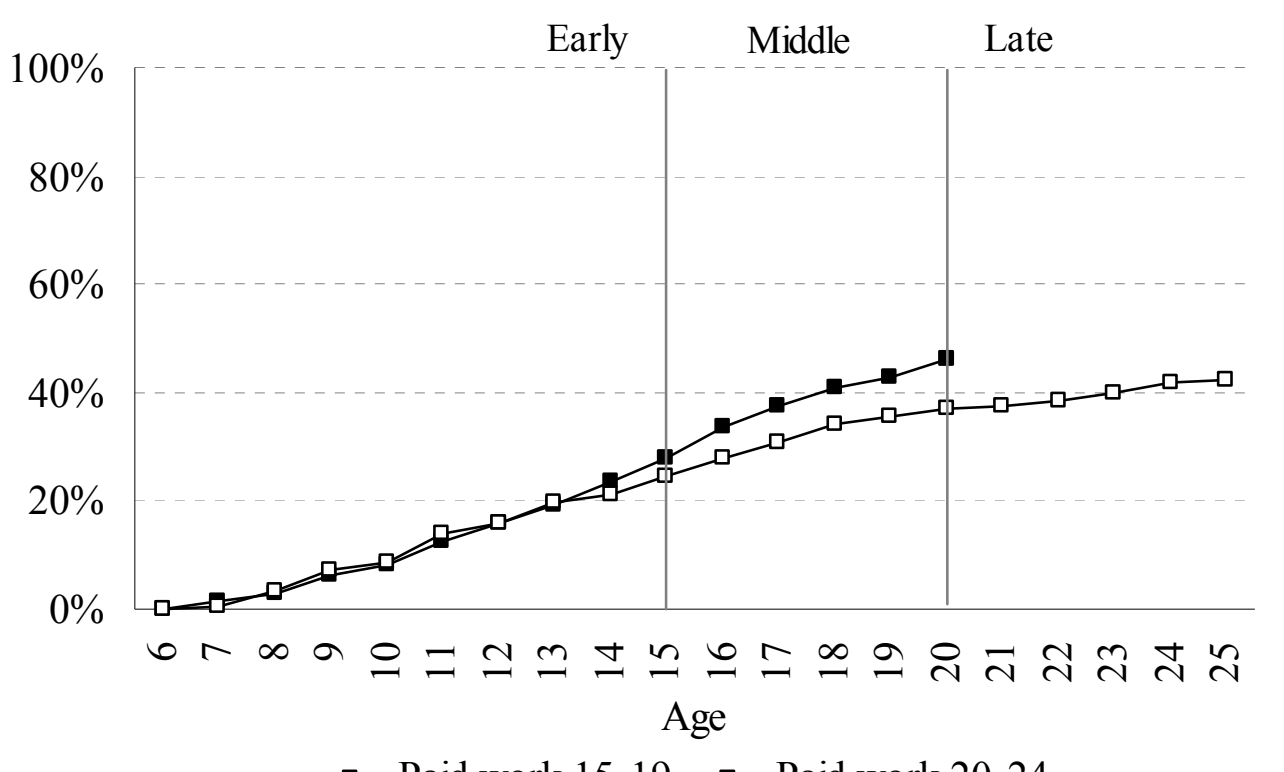

$\rightarrow-$ Paid work 15-19 $\rightarrow$ - Paid work 20-24

(b) Ever attended school

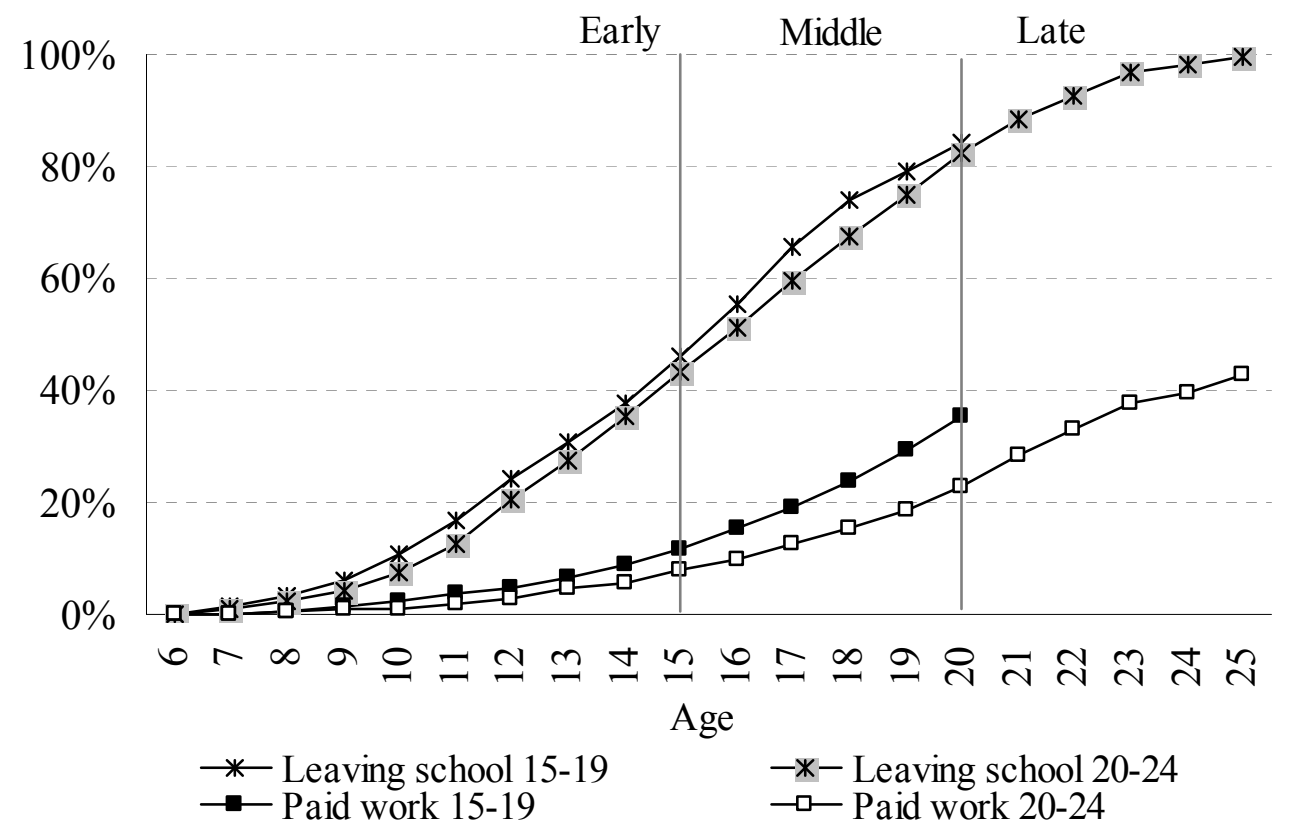

Source: 2001/02 AYSP 
Figure 4 Changes in marriage and leaving home transitions, females

(a) Never attended school

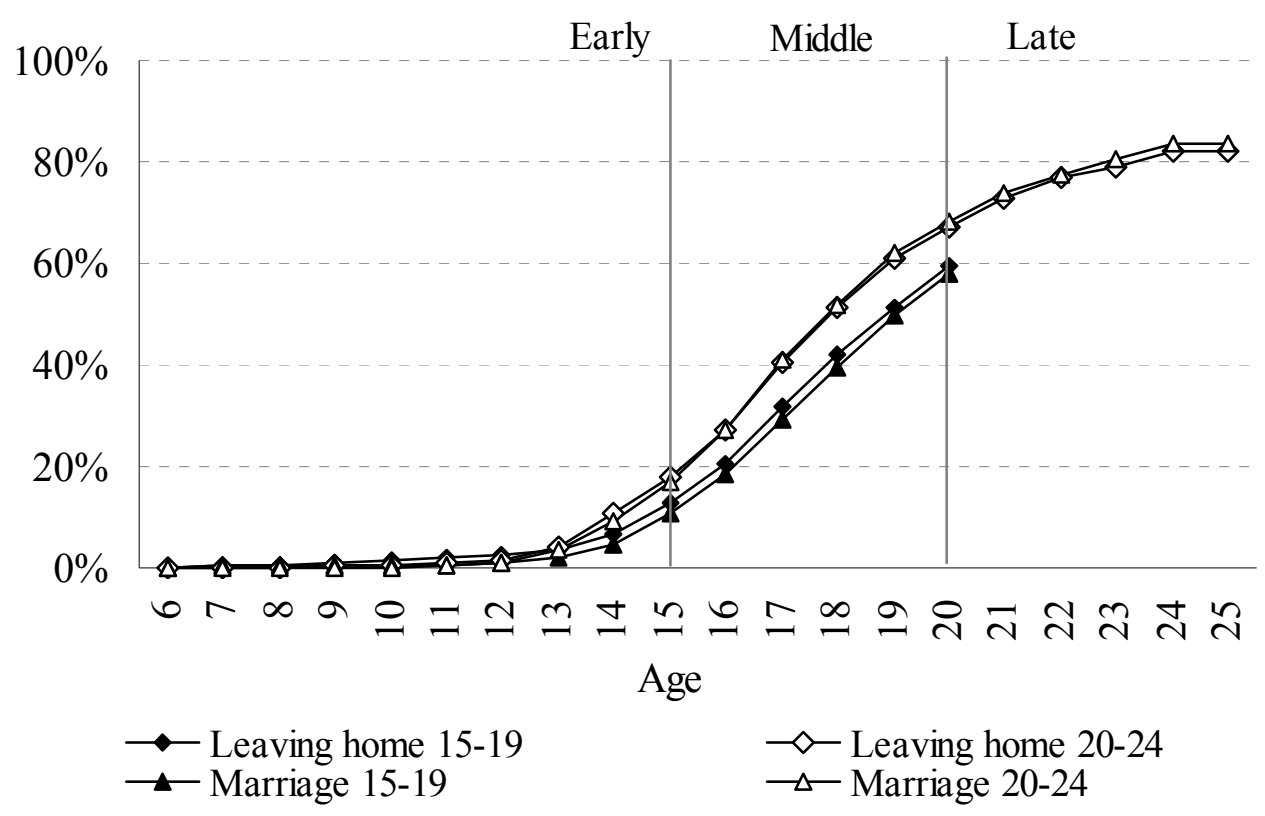

(b) Ever attended school

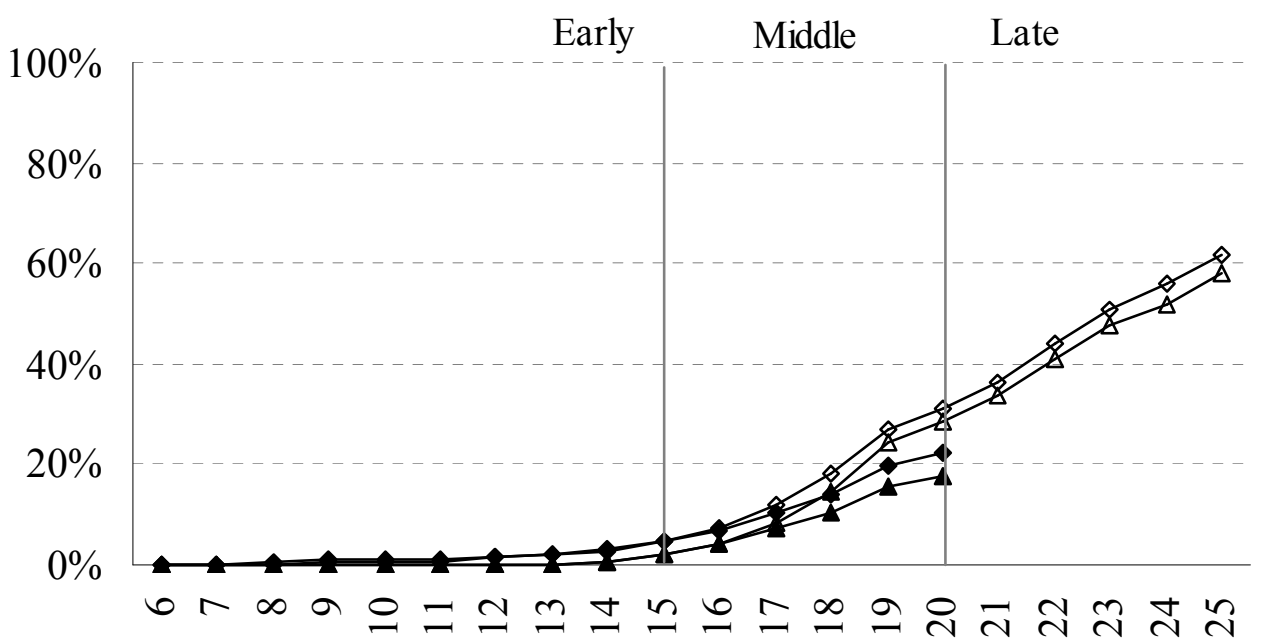

Age

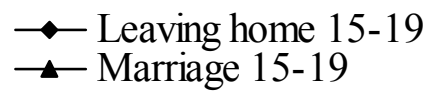

$\rightarrow$ Leaving home 20-24

$\triangle$ Marriage 20-24

Source: 2001/02 AYSP 
Table 3 Distribution of first transitions, by the end of selected ages

\begin{tabular}{|c|c|c|c|c|c|c|}
\hline & \multicolumn{2}{|r|}{14} & \multicolumn{2}{|c|}{19} & \multicolumn{2}{|c|}{24} \\
\hline & Male & Female & Male & Female & Male & Female \\
\hline \multicolumn{7}{|l|}{ Those Who Never } \\
\hline \multicolumn{7}{|l|}{ Attended School } \\
\hline Paid work & 50.4 & 22.1 & 75.4 & 27.9 & 85.0 & 20.0 \\
\hline Leaving parental & & & & & & \\
\hline home & 1.7 & 1.8 & 1.5 & 2.9 & 0.0 & 3.3 \\
\hline Marriage & 0.7 & 0.6 & 1.4 & 2.5 & 0.0 & 3.0 \\
\hline $\begin{array}{l}\text { Paid work and leaving } \\
\text { home }\end{array}$ & 0.8 & 0.0 & 2.4 & 0.1 & 6.2 & 0.0 \\
\hline $\begin{array}{l}\text { Leaving home and } \\
\text { marriage }\end{array}$ & 0.0 & 7.0 & 0.0 & 37.5 & 0.0 & 56.7 \\
\hline No transition & 46.5 & 68.0 & 18.1 & 27.4 & 8.7 & 15.8 \\
\hline Other & 0.0 & 0.5 & 1.2 & 1.7 & 0.0 & 1.3 \\
\hline $\mathrm{N}$ & $535^{\mathrm{a}}$ & $2352^{\mathrm{a}}$ & $218^{\mathrm{b}}$ & $1093^{b}$ & $32^{\mathrm{c}}$ & $164^{\mathrm{c}}$ \\
\hline $\begin{array}{l}\text { Those Who Ever } \\
\text { Attended School }\end{array}$ & & & & & & \\
\hline School leaving & 18.0 & 38.4 & 41.3 & 69.0 & 46.7 & 77.0 \\
\hline Paid work & 9.3 & 4.0 & 15.8 & 7.3 & 24.3 & 11.2 \\
\hline Leaving parental & & & & & & \\
\hline home & 2.6 & 2.2 & 3.6 & 3.8 & 2.9 & 2.4 \\
\hline Marriage & 0.3 & 0.0 & 1.6 & 0.2 & 1.3 & 0.4 \\
\hline $\begin{array}{l}\text { School leaving and } \\
\text { paid work }\end{array}$ & 8.5 & 2.1 & 22.7 & 2.5 & 23.8 & 4.7 \\
\hline No transition & 61.0 & 52.9 & 13.1 & 14.9 & 0.0 & 0.0 \\
\hline Other & 0.3 & 0.3 & 2.0 & 2.3 & 1.0 & 4.2 \\
\hline $\mathrm{N}$ & $2724^{\mathrm{a}}$ & $2451^{\mathrm{a}}$ & $1003^{b}$ & $951^{\mathrm{b}}$ & $133^{\mathrm{c}}$ & $146^{\mathrm{c}}$ \\
\hline
\end{tabular}

Source: 2001/02 AYSP

a all respondents

${ }^{\mathrm{b}}$ respondents aged 20-24

${ }^{c}$ respondents aged 24

In Table 3, we present data on the first transition and indicate how the distribution of first transitions varies by phase of the transition and school enrollment status. We include "no transition" as a category in order to take note of those who have not yet embarked on any transition. ${ }^{7}$ We include single transitions and joint ${ }^{8}$ transitions when they are statistically important. These transitions include first paid work, first departure from home, first marriage, first paid work/marriage, first paid work/departure from home, and first paid work/school exit. For those never attending school, the majority of girls 
(68 percent) had not experienced any transition before age 15 , while 50 percent of males had experienced a first transition into paid work. In the middle phase of the transition, three-quarters of males have experienced a first transition to paid work. Females' experience during this phase of the life cycle is more heterogeneous, divided roughly into thirds among those experiencing their first transition as paid work, the joint transition of leaving home and getting married, and no transition. Very few marry without leaving home or leave home without simultaneously marrying. By age 25, 9 percent of males and 16 percent of females have experienced no transition.

If we look separately at those who ever attended school, it is not surprising that at any age school leaving is likely to be the most common first transition. Marriage and leaving home occur rarely while one is still a student. At each age, many more young females than males have dropped out of school. By age 20, however, 16 percent of young males and 7 percent of young females had entered paid work before leaving school and therefore pursued both activities jointly for a time. By age 25, 24 percent of young males and 11 percent of young females who had ever been to school started paid work before leaving school. Not surprisingly, many more males than females leave school and take up work simultaneously.

The rough duration of each of these three transitions can be measured as the difference between the age at which 25 percent have made the transition and the age at which 75 percent have made the transition (Winsborough 1978). When transitions start late or at very different times and/or last a long time, a longer window of observation is required to capture each transition. Table 4 , which shows the mean age at which each quartile of the transition is reached, demonstrates the difficulty of capturing transitions fully with a survey dedicated to only a decade of life between ages 15 and 24 . For those who never attended school, we are able to observe the full transition to paid work for young males and to marriage and leaving home for young females; each transition lasts about six years. However, while a majority of males eventually marry, the completion of the marriage transition does not occur until well after age 25 . Furthermore, not even a quarter of males have left home by age 24 , given the tradition of bringing a new wife into the natal home. And while all females eventually take up noneconomic household work roles, only a minority ever take up paid work roles at any age. For females, our approach is unable to capture the timing of the work transition.

For those who ever attended school, only the school exit transition can be seen through to completion for both young males and females within our window of observation. The transition to paid work for males is also completed within this time frame, starting and ending later than the same transition among those who never attended school. School exit starts at a younger age for females than males: the first 25 percent of females have exited from school by age 11 as opposed to age 13 for males. On the other hand, the school exit process is slightly more prolonged for females: 6.4 years versus 5 years for males. Given the much later ages of marriage for young females who attend school, we cannot observe the full transition to marriage. The first 50 percent of young educated females have married by the age of 23 ; thus the transition to marriage is not complete by age 24 . 
An exploration of these life tables yields the following preliminary conclusions about the three adult transitions explored in this section. First, the lives of young males and females remain very different: for most young males, the first measured transition is to paid work; for most young females, it is to marriage and leaving home. As we will see below, however, this conclusion is misleading given the domestic work burden most females typically assume at a young age. Furthermore, some transitions occur prematurely: the transition to paid work for those who never attended schoolparticularly for males - and transitions to marriage for females. Second, there are big lags in transitions: young males take up paid work many years before they marry; young females who attend school marry many years after leaving school. As a result of such prolonged transitions, it is not clear when a young person becomes an "adult." Third, the transitions for those who attend school are very different from transitions for those who never attend. Those who attend school are allowed to complete childhood without taking up the burden of work (in the case of females and males) or marriage (in the case of females). Thus, subsequent transitions are already scripted at the time parents decide about school enrollment at the ages of five or six-well before the adolescent years. Fourth, recent changes in the transition are notable for females. In particular, young females (aged 15-19) are more likely to enter paid work during the middle phase of the transition than were their older counterparts (20-24) during the same phase of the transition, whether or not they have ever attended school; they are also more likely to delay marriage whether or not they have been to school.

Table 4 Age by which $25 \%, 50 \%$, and $75 \%$ of cohort has completed each transition and duration of transition

\begin{tabular}{lcc|cc|cc|cc}
\hline & \multicolumn{1}{c}{ Mean Age at Life Table Quartile } & \multicolumn{3}{c}{ Duration } \\
& \multicolumn{2}{c|}{} & $\mathbf{2 5}$ & \multicolumn{2}{c}{$\mathbf{5 0}$} & $\mathbf{7 5}$ & \multicolumn{2}{c}{ Mean Years } \\
& M & $\mathbf{F}$ & $\mathbf{M}$ & $\mathbf{F}$ & $\mathbf{M}$ & $\mathbf{F}$ & $\mathbf{M}$ & $\mathbf{F}$ \\
\hline $\begin{array}{l}\text { Never attended } \\
\text { school }\end{array}$ & & & & & & & & \\
$\quad$ First paid work & 9.8 & 13.7 & 12.7 & $*$ & 16.0 & $*$ & 6.2 & $*$ \\
$\quad$ Leaving home & $*$ & 15.1 & $*$ & 17.3 & $*$ & 21.3 & $*$ & 6.2 \\
First marriage & 19.0 & 15.2 & 22.6 & 17.4 & $*$ & 21.2 & $*$ & 6.0 \\
Ever attended & & & & & & & & \\
school & & & & & & & & \\
$\quad$ Leaving school & 13.2 & 11.3 & 16.0 & 14.6 & 18.2 & 17.7 & 5.0 & 6.4 \\
First paid work & 14.0 & 18.2 & 17.1 & $*$ & 20.6 & $*$ & 6.6 & $*$ \\
Leaving home & $*$ & 18.3 & $*$ & 22.3 & $*$ & $*$ & $*$ & $*$ \\
$\quad$ First marriage & 22.3 & 19.1 & $*$ & 23.1 & $*$ & $*$ & $*$ & $*$ \\
\hline
\end{tabular}

Source: 2001/02 AYSP

*Indicates this quartile was not reached by age 24 . 


\section{Changes in Time USE OVER The Transition to Adulthood}

In a country such as Pakistan, where much work is informal or unpaid and domestic burdens are heavy, the transition to adult work roles is blurred. In this part of the analysis, we focus on changes over the transition in time spent in noneconomic household work (i.e., domestic duties) and time spent on economic activities or labor market work - whether paid work, unpaid work, or in some form of apprenticeshipdrawing on the 24-hour recall data from the time-use profile. Noneconomic household work includes domestic chores inside and outside the house, and the care of children, the sick, and the elderly. While little information on unpaid economic work was reported in the work section of the questionnaire or on the life-event calendar, we picked up considerably more reporting of unpaid economic work in the time-use profile, suggesting that it is often useful to use multiple research methodologies when collecting data on aspects of behavior that are known to be hard to measure. Tables 5 through 7 present descriptive data on time devoted to all types of work including noneconomic household work broken down by type of work, age group, ${ }^{9}$ sex, and current enrollment status. Table 5 shows the percent engaged in each type of work, Table 6 shows the distribution of work time, and Table 7 shows the mean hours worked in each activity (including those who contribute no time to the activity).

Participation in some work is almost universal for young females at all ages, with proportions ranging from 94 percent among 15-16-year-olds to 99 percent of 22-24year-olds (Table 5). Participation in some kind of work rises with age primarily because of a rise in the percent participating in paid work. Among young males the proportion reporting some type of work rises from 69 percent at ages 15-16 to 83 percent at ages 22-24. Fewer males in their 20s report participation in outside noneconomic household work. Males who stay in school into their 20s report much less participation in any type of work. The same is not true for the few young females who remain in school at later ages; their work participation increases with age.

The distribution of work by type does not change by age for females, whether or not they remain in school (Table 6). The same is not true for males. The main difference in the distribution of work between young females who stay in school and those who do not is that those currently enrolled spend almost all their work time on noneconomic household work inside the house (91 percent) while young females out of school spend slightly more time on other activities (21 percent on other activities versus 79 percent on noneconomic household work inside the house). By contrast, the time allocation of young males shifts over the transition, with more time on paid work and less time on domestic chores and unpaid economic activities as they age through the transition. For young males, therefore, part of becoming an adult involves a shift from unpaid economic work for family to outside paid work. There appears to be no such transition for young females, the overwhelming majority of whom start working on noneconomic household work as children and remain in that status as adults.

At all ages, young women's total work time exceeds men's, measured as mean hours worked per day (Table 7). For both sexes, mean hours worked per day rise with age, from 4.1 to 6.6 hours for young males and from 6.7 to 8.6 hours for young females 
starting with the 15-16 age group and ending with the 22-24 age group. ${ }^{10}$ Thus at the end of the transition, young males have achieved the work hours typical of young females at the beginning of the transition. Time spent working is radically different between those currently enrolled and those out of school. The school day appears to be roughly five hours regardless of level. ${ }^{11}$ For young males, those in school report on average 5.5 fewer hours of work than those out of school. For young females, the difference is 6.2 hours. The main reason that work time grows with age for both males and females is that a rising proportion of the sample is out of school at each age. Thus, whether or not we see a close connection between the timing of school leaving and the timing of first paid work, schooling leaving is associated with an immediate assumption of work duties to fill the time previously consumed by school. Furthermore, for young females who work, time is largely spent inside the household, even if working for pay, whereas for males departure from school is associated with the assumption of external paid work.

\section{REDUCED-FORM TIME-USE REGRESSIONS}

To identify some of the factors associated with changes in work time over the course of the transition to adulthood, we estimated reduced-form regression models of work time by work type, using individual, household, and community characteristics as right-hand-side variables. We analyze unpaid economic work time, paid work time, and noneconomic household work separately using Tobit IV estimation to avoid the asymptotic bias of OLS in cases where there are a reasonable percentage of zero observations (see Table 5). ${ }^{12}$ Given the tradeoffs between alternative uses of time, we expect that factors associated with increasing hours spent in one category of work time may be associated with reductions in another category. However, not all uses of time are considered in this analysis.

To explore how other factors affecting time use might vary by phase of the transition, we ran one model with three age dummies and then ran models separately for the younger age cohort representing the middle phase of the transition (15-19) and the older age cohort representing the late phase of the transition (20-24). The means of the variables used in the regressions are presented in Table 8, separately by sex and urban/rural residence status. At the individual and household levels, these variables include whether or not the mother is literate, whether or not the father is literate, the household socioeconomic status in quartiles, various measures of household composition including the number of children under age five, the number of other males and other females aged six to 24, the number of other males and other females 25-64, the number of elderly adults (aged 65+), and, for rural households only, the number of acres of agricultural land. ${ }^{13}$

A key household variable in the analysis is a measure of the household's wealth or socioeconomic status. Following recent arguments that an asset index can serve as a reliable proxy for a household's socioeconomic status (Filmer and Pritchett 1999; Bollen et al. 2002), we used 29 questions from the household survey that pertained to household possessions and amenities as the inputs to a principal components analysis. Following the lead of Filmer and Pritchett (1999), we scored the first component, which can 
reasonably be interpreted as a household's socioeconomic status, and divided it into quartiles of approximately equal size. ${ }^{14}$

In running these regressions, we were particularly interested in the associations between certain community variables and work time, especially variables affecting schooling and work opportunities as well as the availability of basic amenities such as water that would affect time allocation to noneconomic household work. ${ }^{15}$ We include dichotomous variables representing whether or not there was a factory or vocational training institute (for the appropriate sex) within the community or within two kilometers of the community. We also include a series of dummy variables representing the highest level of school available (for the appropriate sex) within or close to the community. ${ }^{16}$ The presence of government water supply was included as well. While we recognize that the placement of community facilities may be endogenous to adolescent outcomes, we do not have historical data on community characteristics that would allow us to model these relationships completely. Thus we recognize that we are measuring associations, not causal relationships.

Tables 9 and 10 present the results for paid work, Tables 11 and 12 the results for unpaid economic work (including unpaid time spent learning a trade), and Tables 13 and 14 the results for work including noneconomic household chores inside and outside the household and care for children, the sick, and the elderly. The results for urban residence are presented in the first table of each pair, the results for rural residence in the second table. The numbers in the table are estimated parameters from the Tobit regressions. In the discussion of regression results below, we comment on the effects of each group of variables across all three categories of work time, pointing out differences in age effects when notable.

Mean daily hours in paid work rise significantly with age over the course of the transition for both young males and young females in urban areas and for young males in rural areas (Tables 9 and 10). This is likely to be linked with school leaving; most females in rural areas have already left school before our period of observation. Males and females aged 22-24 work for pay on average five to six more hours per day than their youngest counterparts (aged 15-16). Rural females in the oldest age group (22-24) experience some significant increase in time devoted to paid work, but much smaller in size (a little over an hour and a half). We see no change with age in time devoted to noneconomic household work for males but a significant increase for females, with a greater increase in hours in urban than rural areas (Tables 13 and 14). This may be explained by the fact that hours spent on noneconomic household work are already high among the youngest rural females aged 15-16 in our analysis. For males aged 22-24 we also see a significant decline of about two hours per day in time in unpaid economic work (Tables 11 and 12). So, while males' increase in paid work is partially offset by a decline in time spent on unpaid economic work as they proceed through the transition, females' paid work time, particularly in urban areas, increases along with time in noneconomic household work, suggesting that they work a "double shift." By contrast, for females in rural areas, work burdens are much heavier overall but do not change much between ages 15 and 24. 
Table 5 Percent reporting time on each category of work activity recorded in time-use profile

\begin{tabular}{|c|c|c|c|c|c|c|c|c|}
\hline \multirow{2}{*}{$\begin{array}{l}\text { Sex and } \\
\text { School Status }\end{array}$} & \multirow[b]{2}{*}{ Age } & \multicolumn{2}{|c|}{$\begin{array}{c}\text { Noneconomic } \\
\text { Household } \\
\text { Work }\end{array}$} & \multirow{2}{*}{$\begin{array}{l}\text { Unpaid } \\
\text { and } \\
\text { Learning }\end{array}$} & \multicolumn{2}{|c|}{ Paid } & \multirow{2}{*}{$\begin{array}{l}\text { Total } \\
\text { Work } \\
\end{array}$} & \multirow[b]{2}{*}{$\mathbf{N}$} \\
\hline & & Inside & Outside & & Inside & Outside & & \\
\hline \multirow{5}{*}{$\begin{array}{l}\text { Male } \\
\text { Not in school }\end{array}$} & $15-16$ & 15.1 & 36.1 & 17.2 & 2.5 & 47.0 & 87.6 & 390 \\
\hline & $17-19$ & 15.4 & 32.2 & 15.1 & 2.6 & 49.4 & 85.1 & 899 \\
\hline & $20-21$ & 13.4 & 25.6 & 14.3 & 3.3 & 53.8 & 84.3 & 507 \\
\hline & $22-24$ & 17.2 & 24.0 & 10.3 & 3.3 & 59.0 & 86.3 & 643 \\
\hline & Total & 15.4 & 29.4 & 14.1 & 2.9 & 52.4 & 85.7 & 2439 \\
\hline \multirow{5}{*}{$\begin{array}{l}\text { Female } \\
\text { Not in school }\end{array}$} & $15-16$ & 97.4 & 19.7 & 9.9 & 9.8 & 10.1 & 98.9 & 946 \\
\hline & $17-19$ & 96.6 & 17.9 & 7.5 & 11.7 & 9.4 & 98.4 & 1297 \\
\hline & $20-21$ & 98.4 & 16.2 & 6.6 & 11.2 & 7.3 & 99.1 & 865 \\
\hline & $22-24$ & 97.6 & 15.7 & 7.2 & 6.9 & 12.4 & 99.0 & 1045 \\
\hline & Total & 97.4 & 17.4 & 7.8 & 9.9 & 9.9 & 98.8 & 4153 \\
\hline \multirow{5}{*}{$\begin{array}{l}\text { Male } \\
\text { in school }\end{array}$} & $15-16$ & 18.8 & 26.2 & 6.4 & 1.1 & 5.6 & 49.9 & 420 \\
\hline & $17-19$ & 12.9 & 22.9 & 7.2 & 0.3 & 6.0 & 43.5 & 294 \\
\hline & $20-21$ & 18.7 & 16.6 & 7.4 & 0.0 & 17.5 & 59.0 & 56 \\
\hline & $22-24$ & 6.6 & 3.0 & 2.3 & 2.2 & 12.6 & 25.7 & 50 \\
\hline & Total & 16.1 & 23.3 & 6.5 & 0.8 & 6.9 & 47.1 & 820 \\
\hline \multirow{5}{*}{$\begin{array}{l}\text { Female } \\
\text { in school }\end{array}$} & $15-16$ & 74.2 & 3.1 & 2.9 & 0.9 & 0.0 & 75.5 & 276 \\
\hline & $17-19$ & 77.8 & 3.9 & 1.5 & 3.8 & 0.7 & 79.7 & 183 \\
\hline & $20-21$ & 64.3 & 13.5 & 0.0 & 3.5 & 4.8 & 67.2 & 36 \\
\hline & $22-24$ & 90.8 & 0.0 & 9.4 & 2.1 & 0.0 & 90.8 & 16 \\
\hline & Total & 75.2 & 4.0 & 2.4 & 2.2 & 0.6 & 76.8 & 511 \\
\hline \multirow{5}{*}{$\begin{array}{l}\text { Male } \\
\text { All }\end{array}$} & $15-16$ & 16.9 & 31.3 & 11.9 & 1.8 & 26.9 & 69.3 & 810 \\
\hline & $17-19$ & 14.9 & 30.1 & 13.4 & 2.1 & 40.0 & 76.1 & 1193 \\
\hline & $20-21$ & 13.9 & 24.8 & 13.7 & 3.0 & 50.4 & 82.0 & 563 \\
\hline & $22-24$ & 16.6 & 22.9 & 9.9 & 3.3 & 56.5 & 83.0 & 693 \\
\hline & Total & 15.6 & 28.0 & 12.3 & 2.4 & 41.9 & 76.8 & 3259 \\
\hline \multirow{5}{*}{$\begin{array}{l}\text { Female } \\
\text { All }\end{array}$} & $15-16$ & 92.6 & 16.2 & 8.4 & 7.9 & 8.0 & 94.1 & 1222 \\
\hline & $17-19$ & 94.5 & 16.4 & 6.9 & 10.8 & 8.4 & 96.4 & 1480 \\
\hline & $20-21$ & 97.3 & 16.1 & 6.3 & 11.0 & 7.2 & 98.0 & 901 \\
\hline & $22-24$ & 97.5 & 15.6 & 7.2 & 6.8 & 12.3 & 98.9 & 1061 \\
\hline & Total & 95.3 & 16.1 & 7.2 & 9.2 & 9.0 & 96.7 & 4664 \\
\hline
\end{tabular}

Source: 2001/02 AYSP 
Table 6 Percent distribution of work time by type recorded in time-use profile

\section{Noneconomic}

Sex and Household Work Unpaid and

Paid

School Status

Inside Outside Learning

Inside Outside

Male Age

Not in school

\begin{tabular}{rrrrrrr}
$15-16$ & 5 & 17 & 17 & 3 & 57 & 390 \\
$17-19$ & 5 & 16 & 14 & 3 & 62 & 899 \\
$20-21$ & 4 & 12 & 13 & 5 & 66 & 507 \\
$22-24$ & 6 & 11 & 8 & 4 & 71 & 643 \\
\hline Total & 5 & 14 & 13 & 4 & 64 & 2439
\end{tabular}

Female

$\begin{array}{lllllll}15-16 & 76 & 6 & 4 & 5 & 9 & 946\end{array}$

Not in school

$17-19 \quad 78 \quad 6 \quad 3$

$\begin{array}{llll}20-21 & 81 & 5 & 3\end{array}$

$6 \quad 7$

1297

\begin{tabular}{rrrrrrr}
$22-24$ & 80 & 5 & 2 & 3 & 10 & 1045 \\
\hline Total & 79 & 5 & 3 & 5 & 8 & 4153
\end{tabular}

Male

$\begin{array}{llll}15-16 & 24 & 44 & 15\end{array}$

15

17-19 19

34

20

2

15

420

in school

20-21 24

16

15

$2 \quad 25$

\begin{tabular}{rrrr}
$22-24$ & 5 & 4 & 4 \\
\hline Total & 22 & 36 & 16
\end{tabular}

$4-11$

Female

in school

\begin{tabular}{rrrrrrr}
$15-16$ & 94 & 2 & 3 & 1 & 0 & 276 \\
$17-19$ & 91 & 3 & 1 & 3 & 2 & 183 \\
$20-21$ & 77 & 7 & 0 & 5 & 12 & 36 \\
$22-24$ & 88 & 0 & 9 & 3 & 0 & 16 \\
\hline Total & 91 & 3 & 2 & 2 & 1 & 511
\end{tabular}

\begin{tabular}{lrrrrrrr} 
& $15-16$ & 8 & 21 & 17 & 3 & 51 & 810 \\
Male & $17-19$ & 6 & 17 & 14 & 3 & 60 & 1193 \\
All & $20-21$ & 5 & 12 & 14 & 4 & 65 & 563 \\
& $22-24$ & 6 & 11 & 8 & 4 & 71 & 693 \\
\cline { 2 - 7 } & Total & 6 & 15 & 13 & 4 & 62 & 3259
\end{tabular}

\begin{tabular}{lrrrrrrr} 
& $15-16$ & 77 & 6 & 4 & 5 & 8 & 1222 \\
Female & $17-19$ & 78 & 5 & 3 & 6 & 7 & 1480 \\
All & $20-21$ & 81 & 5 & 3 & 5 & 5 & 901 \\
& $22-24$ & 81 & 5 & 2 & 3 & 9 & 1061 \\
\cline { 2 - 7 } & Total & 79 & 5 & 3 & 5 & 8 & 4664 \\
\hline
\end{tabular}

Source: 2001/02 AYSP 
Table 7 Mean hours worked per day on each category of work activity recorded in time-use profile

\begin{tabular}{|c|c|c|c|c|c|c|c|c|}
\hline \multirow{2}{*}{$\begin{array}{l}\text { Sex and } \\
\text { School Status }\end{array}$} & \multirow[b]{2}{*}{ Age } & \multicolumn{2}{|c|}{$\begin{array}{c}\text { Noneconomic } \\
\text { Household Work }\end{array}$} & \multirow{2}{*}{$\begin{array}{c}\text { Unpaid } \\
\text { and } \\
\text { Learning }\end{array}$} & \multicolumn{2}{|c|}{ Paid } & \multirow{2}{*}{$\begin{array}{r}\text { Total } \\
\text { Work } \\
\end{array}$} & \multirow[b]{2}{*}{$\mathbf{N}$} \\
\hline & & Inside & Outside & & Inside & Outside & & \\
\hline \multirow{5}{*}{$\begin{array}{l}\text { Male } \\
\text { Not in school }\end{array}$} & $15-16$ & 0.4 & 1.2 & 1.2 & 0.2 & 3.9 & 6.9 & 390 \\
\hline & $17-19$ & 0.4 & 1.0 & 0.9 & 0.2 & 4.1 & 6.6 & 899 \\
\hline & $20-21$ & 0.3 & 0.8 & 0.9 & 0.3 & 4.2 & 6.4 & 507 \\
\hline & $22-24$ & 0.4 & 0.8 & 0.6 & 0.3 & 4.9 & 6.9 & 643 \\
\hline & Total & 0.4 & 0.9 & 0.9 & 0.2 & 4.3 & 6.7 & 2439 \\
\hline \multirow{5}{*}{$\begin{array}{l}\text { Female } \\
\text { Not in school }\end{array}$} & $15-16$ & 6.08 & 0.48 & 0.31 & 0.43 & 0.69 & 7.98 & 946 \\
\hline & $17-19$ & 6.19 & 0.44 & 0.25 & 0.47 & 0.58 & 7.93 & 1297 \\
\hline & $20-21$ & 6.83 & 0.43 & 0.25 & 0.43 & 0.44 & 8.38 & 865 \\
\hline & $22-24$ & 6.94 & 0.39 & 0.20 & 0.27 & 0.82 & 8.63 & 1045 \\
\hline & Total & 6.49 & 0.43 & 0.25 & 0.40 & 0.64 & 8.21 & 4153 \\
\hline \multirow{5}{*}{$\begin{array}{l}\text { Male } \\
\text { in school }\end{array}$} & $15-16$ & 0.3 & 0.5 & 0.2 & 0.0 & 0.2 & 1.1 & 420 \\
\hline & $17-19$ & 0.2 & 0.4 & 0.2 & 0.0 & 0.3 & 1.2 & 294 \\
\hline & $20-21$ & 0.4 & 0.3 & 0.3 & 0.0 & 0.8 & 1.8 & 56 \\
\hline & $22-24$ & 0.1 & 0.0 & 0.0 & 0.1 & 0.8 & 1.0 & 50 \\
\hline & Total & 0.3 & 0.4 & 0.2 & 0.0 & 0.3 & 1.2 & 820 \\
\hline \multirow{5}{*}{$\begin{array}{l}\text { Female } \\
\text { in school }\end{array}$} & $15-16$ & 1.7 & 0.0 & 0.1 & 0.0 & 0.0 & 1.8 & 276 \\
\hline & $17-19$ & 2.0 & 0.1 & 0.0 & 0.1 & 0.0 & 2.2 & 183 \\
\hline & $20-21$ & 1.5 & 0.1 & 0.0 & 0.1 & 0.2 & 1.9 & 36 \\
\hline & $22-24$ & 3.0 & 0.0 & 0.3 & 0.1 & 0.0 & 3.4 & 16 \\
\hline & Total & 1.8 & 0.1 & 0.0 & 0.0 & 0.0 & 2.0 & 511 \\
\hline \multirow{5}{*}{$\begin{array}{l}\text { Male } \\
\text { All }\end{array}$} & $15-16$ & 0.32 & 0.86 & 0.69 & 0.13 & 2.10 & 4.10 & 810 \\
\hline & $17-19$ & 0.33 & 0.90 & 0.77 & 0.15 & 3.26 & 5.41 & 1193 \\
\hline & $20-21$ & 0.28 & 0.73 & 0.81 & 0.27 & 3.93 & 6.02 & 563 \\
\hline & $22-24$ & 0.38 & 0.72 & 0.52 & 0.30 & 4.67 & 6.59 & 693 \\
\hline & Total & 0.33 & 0.82 & 0.71 & 0.19 & 3.38 & 5.43 & 3259 \\
\hline \multirow{5}{*}{$\begin{array}{l}\text { Female } \\
\text { All }\end{array}$} & $15-16$ & 5.17 & 0.39 & 0.26 & 0.35 & 0.54 & 6.70 & 1222 \\
\hline & $17-19$ & 5.72 & 0.40 & 0.23 & 0.43 & 0.52 & 7.29 & 1480 \\
\hline & $20-21$ & 6.65 & 0.42 & 0.24 & 0.42 & 0.43 & 8.16 & 901 \\
\hline & $22-24$ & 6.90 & 0.39 & 0.20 & 0.27 & 0.81 & 8.57 & 1061 \\
\hline & Total & 6.04 & 0.40 & 0.23 & 0.37 & 0.58 & 7.61 & 4664 \\
\hline
\end{tabular}

Source: 2001/02 AYSP 
Table 8 Descriptive statistics for estimation of Tobit regressions of time-use determinants

\begin{tabular}{|c|c|c|c|c|}
\hline & \multicolumn{2}{|c|}{ Male } & \multicolumn{2}{|c|}{ Female } \\
\hline & Rural & Urban & Rural & Urban \\
\hline \multicolumn{5}{|l|}{ Dependent Variables } \\
\hline Noneconomic household work, hours/day & 1.43 & 0.51 & 6.91 & 5.18 \\
\hline Unpaid economic work & & & & \\
\hline \& learning skills, hours/day & 0.77 & 0.57 & 0.26 & 0.16 \\
\hline Paid work, hours/day & 3.51 & 3.70 & 1.06 & 0.65 \\
\hline \multicolumn{5}{|l|}{ Independent Variables } \\
\hline \multicolumn{5}{|l|}{ Age variables (15-16 omitted) } \\
\hline $17-19$ & 36.28 & 38.75 & 31.26 & 33.31 \\
\hline $20-21$ & 15.98 & 18.34 & 19.31 & 19.06 \\
\hline $22-24$ & 21.12 & 20.78 & 23.97 & 22.51 \\
\hline Mother's literacy $=1$ & 6.38 & 29.81 & 5.56 & 29.07 \\
\hline Father's literacy $=1$ & 37.73 & 64.78 & 34.21 & 58.96 \\
\hline \multicolumn{5}{|l|}{ Household socioeconomic status (low omitted) } \\
\hline Low-mid & 30.00 & 6.27 & 31.87 & 5.42 \\
\hline High-mid & 26.09 & 27.05 & 25.83 & 27.17 \\
\hline High & 14.04 & 65.13 & 11.18 & 66.29 \\
\hline \multicolumn{5}{|l|}{ Household composition } \\
\hline Number of children $0-5$ years old & 1.53 & 0.89 & 1.76 & 1.13 \\
\hline Number of males 6-24 years old & 2.97 & 2.96 & 2.00 & 1.98 \\
\hline Number of females 6-24 years old & 2.22 & 2.03 & 2.70 & 2.71 \\
\hline Number of males $25-64$ years old & 1.36 & 1.39 & 1.44 & 1.51 \\
\hline Number of females $25-64$ years old & 1.41 & 1.35 & 1.29 & 1.30 \\
\hline Number of elderly 65 years and older & 0.32 & 0.22 & 0.34 & 0.24 \\
\hline Government water supply (yes $=1$ ) & 14.66 & 75.52 & 16.01 & 73.98 \\
\hline Factory $($ yes $=1)$ & 17.64 & 61.73 & 17.05 & 60.24 \\
\hline Vocational institute $($ yes $=1)$ & 2.31 & 13.00 & 3.08 & 26.6 \\
\hline \multicolumn{5}{|l|}{ Highest available educational level } \\
\hline Middle $($ yes $=1)$ & 16.95 & 7.46 & 17.78 & 9.9 \\
\hline Secondary $($ yes $=1)$ & 22.65 & 56.29 & 11.97 & 54.12 \\
\hline Higher secondary $($ yes $=1)$ & 10.97 & 28.92 & 5.57 & 28.03 \\
\hline
\end{tabular}

Source: 2001/02 AYSP 
Having literate parents (controlling for socioeconomic status) appears to be associated with a reduction in paid work time for rural females and for rural and urban males (Tables 9 and 10). Having a literate mother is relatively more beneficial than having a literate father for males in urban areas and for females in rural areas; having a literate father is beneficial for males in rural areas. Having literate parents is also associated with reduced time in noneconomic household work for young females in urban areas, with reductions in work time being associated with mother's literacy among younger females and with father's literacy among older females (Table 13).

Because of the way our household wealth quartiles were constructed, we see few statistically significant associations of household wealth with hours of work in urban areas. We see the biggest associations of household wealth in Table 10 with paid work in rural areas. For young males, the groups with higher socioeconomic status work about two hours less than the lowest socioeconomic group; for young females the time-use differentials are much greater, with a gap exceeding four hours per day between the highest and lowest wealth group. These associations are most apparent for the youngest age group, where females in the wealthiest households work six fewer hours than those in the poorest. For young females, being in the highest quartile of the wealth distribution is associated with a small but statistically significant decline in noneconomic household work time in both urban (Table 13) and rural areas (Table 14).

Household composition is strongly associated with variations in paid work time among young males and females in rural areas (Table 10). ${ }^{17}$ The signs of particular household composition variables almost always have opposite effects for young males compared with young females, suggesting that rising household size reinforces the traditional gender division of labor. The presence of females of any age is associated with significant reductions in the paid work time of males but at the same time increases the paid work time of young females; this suggests that the presence of more females in the household allows a division of labor between them, with some working at home and others working outside the home. The presence of other young males in the household is associated with an increase in the paid work time of young men. The presence of young children has a small negative association with paid work time for females in urban areas (Table 9). Household composition is a particularly important factor in young females' time spent on noneconomic household work in both urban and rural areas (Tables 13 and 14), and the sizes of the associations of different variables are similar. The presence of children, elderly, and young men is associated with increased time in females' noneconomic household work, and the presence of other females of any age is associated with a reduction in noneconomic household work, particularly so when older females are present. For young males, time in noneconomic household work, which is always small in any case, is rarely affected by household composition. 
Table 9 Results of time-use Tobit regressions: paid work, urban ${ }^{\mathrm{a}}$

\begin{tabular}{|c|c|c|c|c|c|c|}
\hline \multirow[b]{2}{*}{ Variables } & \multicolumn{3}{|c|}{ Male } & \multicolumn{3}{|c|}{ Female } \\
\hline & Total & 15-19 & $20-24$ & Total & 15-19 & 20-24 \\
\hline Individual & 1303 & 797 & 506 & 1716 & 1003 & 713 \\
\hline \multicolumn{7}{|l|}{$\begin{array}{l}\text { Age dummy (15-16 } \\
\text { omitted) }\end{array}$} \\
\hline $17-19$ & $3.909 * * *$ & $4.029 * * *$ & n.a. & $3.050 * * *$ & $3.027 * * *$ & n.a. \\
\hline $20-21$ & $4.276^{* * *}$ & n.a. & n.a. & $3.847 * * *$ & n.a. & n.a. \\
\hline $22-24$ & $6.464 * * *$ & n.a. & $2.126 * *$ & $5.308 * * *$ & n.a. & 1.409 \\
\hline Mother literate $=1$ & $-4.925 * * *$ & $-6.604 * * *$ & $-3.167 * *$ & 0.006 & -0.853 & 0.838 \\
\hline Father literate $=1$ & $-1.816^{* *}$ & -1.602 & $-1.811 *$ & -1.240 & -2.823 & 0.990 \\
\hline
\end{tabular}

Household

Household wealth quartile dummy (1 omitted)

$\begin{array}{lcccccc}2 & 2.719 & 2.503 & 3.776 & 1.428 & -0.352 & 3.268 \\ 3 & 1.393 & 1.366 & 2.250 & -1.100 & -1.743 & -0.521 \\ 4 & 0.832 & 0.204 & 2.091 & -3.458 & -3.444 & -3.883 \\ \text { Number of children 0-5 } & 0.271 & 0.034 & 0.546^{*} & -0.498^{*} & -0.146 & -0.394 \\ \text { Number of males 6-24 } & 0.106 & -0.032 & 0.295 & 0.408 & 0.517^{*} & 0.218 \\ \text { Number of females 6-24 } & -0.356 & -0.559^{*} & -0.031 & 0.150 & -0.331 & 0.710^{* *} \\ \text { Number of males 25-64 } & -0.306 & 0.390 & -0.827 & -0.834 & -0.447 & -1.255^{*} \\ \text { Number of females 25-64 } & -0.174 & -0.307 & -0.238 & -0.072 & -1.343^{* *} & 0.491 \\ \text { Number of elderly 65+ } & -0.043 & -0.038 & -0.643 & 0.106 & 0.621 & -0.657 \\ \text { Number of agricultural } & & & & & & \text { n.a. } \\ \text { acres } & \text { n.a. } & \text { n.a. } & \text { n.a. } & & \text { n.a. }\end{array}$

\section{Community}

Government water supply

$=1$

Factory $=1$

Vocational institute $=1$

Highest school available (none omitted)

\begin{tabular}{lcccccc} 
Middle $=1$ & 0.991 & 0.180 & 1.449 & -2.640 & -2.440 & -4.597 \\
Secondary = 1 & -0.701 & -0.825 & -0.681 & $-4.355^{* *}$ & $-5.165^{* * *}$ & -3.598 \\
Higher secondary = 1 & 0.495 & 0.867 & -0.212 & $-4.224^{*}$ & $-5.273^{* *}$ & -3.757 \\
\hline
\end{tabular}

Source: 2001/02 AYSP

${ }^{\mathrm{a}}$ Controlling for province, month of interview, day of week, standard errors corrected for clustering on PSUs.

n.a. = not applicable

* $\quad$ Statistically significant at $10 \%$ level

** $\quad$ Statistically significant at 5\% level

$* * *$ Statistically significant at $1 \%$ level 
Table 10 Results of time-use Tobit regressions: paid work, rural ${ }^{\mathrm{a}}$

\begin{tabular}{|c|c|c|c|c|c|c|}
\hline \multirow[b]{2}{*}{ Variables } & \multicolumn{3}{|c|}{ Male } & \multicolumn{3}{|c|}{ Female } \\
\hline & Total & 15-19 & $20-24$ & Total & 15-19 & 20-24 \\
\hline Individual & 1704 & 1062 & 642 & 2625 & 1512 & 1113 \\
\hline \multicolumn{7}{|l|}{$\begin{array}{l}\text { Age dummy (15-16 } \\
\text { omitted) }\end{array}$} \\
\hline $17-19$ & $2.305 * *$ & $2.426 * *$ & n.a. & 0.964 & 0.938 & n.a. \\
\hline $20-21$ & $4.494 * * *$ & n.a. & n.a. & 0.400 & n.a. & n.a. \\
\hline $22-24$ & $5.588 * * *$ & n.a. & 0.946 & $1.522^{*}$ & n.a. & 1.147 \\
\hline Mother literate $=1$ & -1.472 & -1.745 & -1.269 & $-6.684 * * *$ & $-8.057 * * *$ & -5.276 \\
\hline Father literate $=1$ & $-3.710 * * *$ & $-4.956 * * *$ & $-2.372 * *$ & $-1.673 * *$ & $-1.722 * *$ & -1.330 \\
\hline
\end{tabular}

Household

Household wealth quartile dummy (1 omitted)

\begin{tabular}{|c|c|c|c|c|c|c|}
\hline 2 & $-2.030 * * *$ & $-2.898 * * *$ & -0.889 & $-1.801 * * *$ & $-2.139 * *$ & -1.303 \\
\hline 3 & $-2.023 * * *$ & $-2.536 * *$ & -1.241 & $-2.532 * * *$ & $-3.604 * * *$ & -1.424 \\
\hline 4 & $-2.575^{*}$ & -2.000 & $-2.954 * *$ & $-4.331 * * *$ & $-5.967 * * *$ & -2.325 \\
\hline Number of children $0-5$ & 0.088 & 0.094 & 0.154 & -0.073 & -0.284 & 0.079 \\
\hline Number of males 6-24 & $0.615 * * *$ & $0.683 * * *$ & $0.534 * *$ & -0.216 & -0.125 & -0.339 \\
\hline Number of females 6-24 & $-0.364 *$ & -0.401 & -0.314 & $0.337 * *$ & 0.290 & $0.424 *$ \\
\hline Number of males 25-64 & 0.125 & -0.083 & 0.344 & -0.434 & -0.131 & $-0.783 *$ \\
\hline Number of females 25-64 & $-1.076 * *$ & -0.626 & $-1.631 * * *$ & $0.875 * *$ & $1.115^{* *}$ & 0.657 \\
\hline Number of elderly $65+$ & -0.304 & -0.411 & -0.205 & -0.180 & -0.034 & -0.471 \\
\hline $\begin{array}{l}\text { Number of agricultural } \\
\text { acres }\end{array}$ & -0.021 & $-0.039 * *$ & -0.009 & -0.015 & -0.006 & -0.025 \\
\hline \multicolumn{7}{|l|}{ Community } \\
\hline $\begin{array}{l}\text { Government water supply } \\
=1\end{array}$ & -0.897 & $-2.116^{*}$ & 0.547 & -1.062 & -0.382 & -1.691 \\
\hline Factory $=1$ & $2.025^{* *}$ & $2.478 * *$ & $1.637^{*}$ & $3.071 * * *$ & $2.897 * *$ & $3.361 * * *$ \\
\hline Vocational institute $=1$ & 2.267 & -1.096 & $7.048 * * *$ & 1.017 & 1.784 & -0.469 \\
\hline \multicolumn{7}{|l|}{$\begin{array}{l}\text { Highest school available } \\
\text { (none omitted) }\end{array}$} \\
\hline Middle & -0.802 & -0.976 & -0.845 & $-2.830 * *$ & $-3.073 * *$ & $-2.827 * *$ \\
\hline Secondary & $-1.810^{*}$ & -2.061 & -1.419 & $-4.453 * * *$ & $-3.752 * * *$ & $-5.740 * * *$ \\
\hline Higher secondary & -0.009 & 0.458 & -0.179 & -2.487 & -0.617 & $-4.780 * *$ \\
\hline
\end{tabular}

Source: 2001/02 AYSP

${ }^{a}$ Controlling for province, month of interview, day of week, standard errors corrected for clustering on PSUs.

n.a. $=$ not applicable

* Statistically significant at $10 \%$ level

** Statistically significant at 5\% level

*** Statistically significant at $1 \%$ level 
Table 11 Results of time-use Tobit regressions: unpaid economic work, urban ${ }^{\mathrm{a}}$

\begin{tabular}{|c|c|c|c|c|c|c|}
\hline \multirow[b]{2}{*}{ Variables } & \multicolumn{3}{|c|}{ Male } & \multicolumn{3}{|c|}{ Female } \\
\hline & Total & $15-19$ & $20-24$ & Total & 15-19 & $20-24$ \\
\hline Individual & 1303 & 797 & 506 & 1716 & 1003 & 713 \\
\hline \multicolumn{7}{|l|}{$\begin{array}{l}\text { Age dummy (15-16 } \\
\text { omitted) }\end{array}$} \\
\hline $17-19$ & -1.887 & -2.016 & n.a. & -0.560 & -0.252 & n.a. \\
\hline $20-21$ & -0.130 & n.a. & n.a. & 1.026 & n.a. & n.a. \\
\hline $22-24$ & $-2.552^{*}$ & n.a. & $-2.791 *$ & -1.226 & n.a. & -2.369 \\
\hline Mother literate $=1$ & 0.107 & 0.599 & -0.194 & $-2.199 *$ & -1.781 & $-3.079 *$ \\
\hline Father literate $=1$ & -0.935 & -1.347 & 0.764 & -0.481 & -0.920 & -0.258 \\
\hline
\end{tabular}

Household

Household wealth quartile dummy (1 omitted)

$\begin{array}{lcccccc}2 & 4.600^{*} & 5.744^{*} & -0.717 & 1.431 & 1.021 & 1.582 \\ 3 & 0.712 & 3.007 & -7.104 & -0.114 & -0.361 & 1.667 \\ 4 & 1.920 & 3.159 & -4.331 & 0.957 & 0.077 & 3.343^{*} \\ \text { Number of children 0-5 } & 0.311 & 0.369 & 0.460 & 0.116 & 0.447 & -0.413 \\ \text { Number of males 6-24 } & 0.294 & 0.411 & -0.027 & 0.453 & 0.645^{*} & -0.025 \\ \text { Number of females 6-24 } & -0.059 & -0.041 & -0.101 & 0.061 & 0.309 & 0.033 \\ \text { Number of males 25-64 } & 0.865^{*} & 0.729 & 1.320^{* *} & -0.706^{*} & -1.680^{* * *} & 0.015 \\ \text { Number of females 25-64 } & -1.265^{*} & -2.820^{* * *} & -0.457 & -0.389 & -0.304 & -0.379 \\ \text { Number of elderly 65+ } & 1.230 & 2.176^{*} & -0.184 & 0.075 & -0.684 & 0.837 \\ \text { Number of agricultural } & & & & & & \text { n.a. } \\ \text { acres } & \text { n.a. } & \text { n.a. } & \text { n.a. } & \text { n.a. }\end{array}$

Community

Government water supply

\begin{tabular}{lcccccc}
$=1$ & $-2.445^{* *}$ & -1.937 & $-3.661^{* *}$ & -0.325 & -0.885 & 0.505 \\
Factory = 1 & 0.705 & $2.396^{*}$ & $-2.521^{*}$ & 1.476 & 1.817 & 1.443 \\
Vocational institute $=1$ & 0.750 & 1.229 & -0.119 & -0.738 & -0.877 & -1.374 \\
$\begin{array}{l}\text { Highest school available } \\
\text { (none omitted) }\end{array}$ & & & & & & \\
$\quad \begin{array}{l}\text { Middle } \\
\text { Secondary }\end{array}$ & 1.381 & -2.533 & $7.054^{* *}$ & 3.233 & 1.352 & $5.505^{* *}$ \\
Higher secondary & -2.207 & -3.752 & 1.034 & 2.551 & 2.444 & 2.508 \\
\hline
\end{tabular}

Source: 2001/02 AYSP

${ }^{a}$ Controlling for province, month of interview, day of week, standard errors corrected for clustering on PSUs.

n.a. = not applicable

* Statistically significant at $10 \%$ level

** Statistically significant at 5\% level

$* * *$ Statistically significant at $1 \%$ level 
Table 12 Results of time-use Tobit regressions: unpaid economic work, rural ${ }^{\mathrm{a}}$

\begin{tabular}{|c|c|c|c|c|c|c|}
\hline \multirow[b]{2}{*}{ Variables } & \multicolumn{3}{|c|}{ Male } & \multicolumn{3}{|c|}{ Female } \\
\hline & Total & $15-19$ & $20-24$ & Total & $15-19$ & $20-24$ \\
\hline Individual & 1704 & 1062 & 642 & 2625 & 1512 & 1113 \\
\hline $\begin{array}{l}\text { Age dummy (15-16 } \\
\text { omitted) }\end{array}$ & & & & & & \\
\hline $17-19$ & 0.532 & 0.397 & n.a. & -0.298 & -0.313 & n.a. \\
\hline $20-21$ & 0.438 & n.a. & n.a. & -0.944 & n.a. & n.a. \\
\hline $22-24$ & $-2.356 * *$ & n.a. & $-2.938 * *$ & 0.142 & n.a. & 1.048 \\
\hline Mother literate $=1$ & -3.162 & $-4.477 *$ & 0.212 & 1.816 & 1.953 & 2.041 \\
\hline Father literate $=1$ & 0.051 & -1.146 & $2.445^{*}$ & -0.863 & -0.587 & -1.377 \\
\hline
\end{tabular}

Household

Household wealth quartile dummy (1 omitted)

$\begin{array}{lcccccc}2 & 0.211 & 0.494 & -0.275 & 0.317 & 0.730 & -0.593 \\ 3 & -0.253 & -0.719 & 0.405 & -1.283 & -2.348^{*} & -0.624 \\ 4 & -0.071 & 0.823 & -1.520 & -2.142 & -2.204 & -3.074^{*} \\ \text { Number of children 0-5 } & -0.018 & -0.128 & 0.277 & -0.166^{* *} & -0.215 & -0.213 \\ \text { Number of males 6-24 } & -0.735^{* *} & -0.669^{*} & -0.902^{* *} & -0.170 & -0.306 & 0.026 \\ \text { Number of females 6-24 } & 0.265 & 0.298 & 0.398 & 0.116 & 0.047 & 0.376 \\ \text { Number of males 25-64 } & 0.718 & 0.754 & 0.608 & -0.123 & -0.406 & 0.106 \\ \text { Number of females 25-64 } & 0.064 & 0.149 & 0.150 & 0.500 & 0.388 & 0.409 \\ \text { Number of elderly 65+ } & 1.298 & 0.586 & 2.601^{*} & -0.585 & -0.789 & -0.581 \\ \text { Number of agricultural } & & & & & & \\ \text { acres } & 0.010 & 0.011 & 0.006 & 0.011^{*} & 0.011 & 0.019^{* *}\end{array}$

Community

Government water supply

\begin{tabular}{lcccccc}
$=1$ & -0.762 & -1.585 & 0.543 & $-2.109 * *$ & $-2.149 * *$ & $-2.292^{*}$ \\
Factory $=1$ & 0.022 & -0.004 & 1.059 & -0.831 & 1.267 & $-3.660^{* * *}$ \\
$\begin{array}{l}\text { Vocational institute }=1 \\
\text { Highest school available }\end{array}$ & -2.925 & -1.130 & -6.941 & 2.901 & -1.834 & $7.995^{* * *}$ \\
$\begin{array}{l}\text { (none omitted) } \\
\text { Middle }\end{array}$ & & & & & & \\
Secondary & 0.749 & 1.854 & -1.831 & -0.856 & $-2.468 * *$ & 1.075 \\
Higher secondary & 1.227 & 1.743 & 0.390 & -0.829 & -0.480 & -1.586 \\
\hline
\end{tabular}

Source: 2001/02 AYSP

${ }^{\mathrm{a}}$ Controlling for province, month of interview, day of week, standard errors corrected for clustering on PSUs.

n.a. $=$ not applicable

* Statistically significant at $10 \%$ level

** Statistically significant at 5\% level

*** Statistically significant at $1 \%$ level 
Table 13 Results of time-use Tobit regressions: noneconomic household work, urban ${ }^{\mathrm{a}}$

\begin{tabular}{lccccccc}
\hline & \multicolumn{3}{c}{ Male } & & \multicolumn{3}{c}{ Female } \\
\cline { 2 - 3 } \cline { 6 - 8 } Variables & Total & $\mathbf{1 5 - 1 9}$ & $\mathbf{2 0 - 2 4}$ & & Total & $\mathbf{1 5 - 1 9}$ & $\mathbf{2 0 - 2 4}$ \\
\hline $\begin{array}{l}\text { Individual } \\
\begin{array}{l}\text { Age dummy } \\
\text { omitted) }\end{array}\end{array}$ & 1303 & 797 & 506 & & 1716 & 1003 & 713 \\
$17-19$ & & & & & & & \\
$20-21$ & -0.363 & -0.346 & n.a. & & $1.083^{* * *}$ & $1.078^{* * *}$ & n.a. \\
$22-24$ & -0.459 & n.a. & n.a. & & $2.392^{* * *}$ & n.a. & n.a. \\
Mother literate $=1$ & -0.404 & n.a. & 0.019 & & $2.660^{* * *}$ & n.a. & 0.223 \\
Father literate $=1$ & 0.287 & -0.027 & 0.811 & & $-1.026^{* *}$ & $-1.477^{* * *}$ & -0.431 \\
& -0.247 & -0.229 & -0.513 & & $-0.732^{* *}$ & -0.669 & $-0.911^{* * *}$
\end{tabular}

Household

Household wealth quartile dummy (1 omitted)

$\begin{array}{lcccccc}2 & -1.449 & -0.588 & -3.968^{*} & -0.406 & -0.051 & -0.762 \\ 3 & -0.177 & 0.325 & -2.098 & -0.971^{*} & -0.594 & -1.254^{* *} \\ 4 & -0.735 & -0.339 & -2.049 & -1.666^{* * *} & -1.732^{*} & -1.226^{* *} \\ \text { Number of children 0-5 } & -0.136 & -0.177 & -0.142 & 0.453^{* * *} & 0.296^{* *} & 0.596^{* * *} \\ \text { Number of males 6-24 } & -0.099 & -0.022 & -0.182 & 0.198^{* *} & 0.188^{*} & 0.263 \\ \text { Number of females 6-24 } & -0.128 & -0.128 & -0.111 & -0.165^{*} & -0.062 & -0.275^{*} \\ \text { Number of males 25-64 } & -0.110 & -0.162 & -0.009 & 0.249 & 0.229 & 0.219 \\ \text { Number of females 25-64 } & 0.263 & 0.399 & -0.084 & -0.814^{* * *} & -0.713 * * * & -0.891^{* * *} \\ \text { Number of elderly 65+ } & -0.197 & -0.309 & 0.115 & 0.220 & 0.255 & 0.235 \\ \text { Number of agricultural } & & & & & & \text { n.a. } \\ \text { acres } & \text { n.a. } & \text { n.a. } & \text { n.a. } & & & \text { n.a. }\end{array}$

\section{Community}

Government water supply

$=1$

Factory $=1$

Vocational institute $=1$

Highest school available (none omitted)

\begin{tabular}{lcccccc} 
Middle & 0.270 & 0.775 & -0.709 & 0.691 & 0.416 & 1.060 \\
Secondary & 0.428 & 0.517 & 0.008 & 0.607 & 0.712 & 0.576 \\
Higher secondary & 0.123 & 0.212 & -0.180 & 0.749 & 1.092 & 0.477 \\
\hline
\end{tabular}

Source: 2001/02 AYSP

${ }^{a}$ Controlling for province, month of interview, day of week, standard errors corrected for clustering on PSUs.

n.a. $=$ not applicable

* Statistically significant at $10 \%$ level

** Statistically significant at 5\% level

*** Statistically significant at $1 \%$ level 
Table 14 Results of time-use Tobit regressions: noneconomic household work, rural ${ }^{\mathrm{a}}$

\begin{tabular}{|c|c|c|c|c|c|c|}
\hline \multirow[b]{2}{*}{ Variables } & \multicolumn{3}{|c|}{ Male } & \multicolumn{3}{|c|}{ Female } \\
\hline & Total & 15-19 & 20-24 & Total & $15-19$ & $20-24$ \\
\hline Individual & 1704 & 1062 & 642 & 2625 & 1512 & 1113 \\
\hline \multicolumn{7}{|l|}{$\begin{array}{l}\text { Age dummy (15-16 } \\
\text { omitted) }\end{array}$} \\
\hline $17-19$ & 0.009 & -0.029 & n.a. & $0.416 * *$ & $0.438 * *$ & n.a. \\
\hline $20-21$ & -0.695 & n.a. & n.a. & $1.057 * * *$ & n.a. & n.a. \\
\hline $22-24$ & -0.588 & n.a. & 0.174 & $0.938 * * *$ & n.a. & -0.167 \\
\hline Mother literate $=1$ & -0.807 & -0.999 & -0.241 & -0.212 & -0.181 & -0.133 \\
\hline Father literate $=1$ & 0.026 & -0.382 & 0.761 & -0.256 & -0.320 & -0.121 \\
\hline
\end{tabular}

Household

Household wealth quartile dummy (1 omitted)

\begin{tabular}{|c|c|c|c|c|c|c|}
\hline 2 & -0.007 & 0.208 & -0.599 & -0.173 & $-0.494 *$ & 0.242 \\
\hline 3 & $-0.848 * *$ & -0.343 & $-1.626 * * *$ & -0.059 & -0.369 & 0.399 \\
\hline 4 & $-1.641 * * *$ & -0.966 & $-2.567 * * *$ & $-0.788 * * *$ & $-1.205 * * *$ & -0.457 \\
\hline Number of children $0-5$ & -0.045 & 0.036 & -0.148 & $0.327 * * *$ & $0.369 * * *$ & $0.304 * * *$ \\
\hline Number of males 6-24 & $-0.176^{*}$ & $-0.193 *$ & -0.191 & $0.115^{*}$ & $0.155^{* *}$ & 0.047 \\
\hline Number of females 6-24 & 0.039 & 0.130 & -0.078 & $-0.196 * * *$ & $-0.212 * *$ & $-0.158 * *$ \\
\hline Number of males 25-64 & 0.148 & 0.136 & 0.046 & -0.032 & -0.183 & 0.153 \\
\hline Number of females 25-64 & 0.140 & -0.088 & $0.590 * *$ & $-0.489 * * *$ & $-0.451 * * *$ & $-0.556 * * *$ \\
\hline Number of elderly $65+$ & 0.232 & 0.350 & 0.091 & $0.245^{* *}$ & $0.267 *$ & 0.169 \\
\hline $\begin{array}{l}\text { Number of agricultural } \\
\text { acres }\end{array}$ & -0.005 & -0.004 & -0.009 & -0.003 & -0.004 & 0.000 \\
\hline \multicolumn{7}{|l|}{ Community } \\
\hline $\begin{array}{l}\text { Government water supply } \\
=1\end{array}$ & -0.498 & 0.144 & $-1.965 * * *$ & -0.049 & -0.129 & 0.159 \\
\hline Factory $=1$ & $-1.131 * *$ & $-1.191^{*}$ & $-1.226^{*}$ & $-0.469 *$ & $-0.637 * *$ & -0.162 \\
\hline Vocational institute $=1$ & $-2.853 * *$ & -2.464 & $-3.451 * * *$ & -0.171 & -0.284 & -0.067 \\
\hline \multicolumn{7}{|l|}{$\begin{array}{l}\text { Highest school available } \\
\text { (none omitted) }\end{array}$} \\
\hline Middle & -0.288 & -0.489 & 0.251 & 0.357 & 0.107 & $0.638^{*}$ \\
\hline Secondary & -0.444 & -0.880 & 0.253 & 0.349 & -0.227 & $1.084 * *$ \\
\hline Higher secondary & 0.028 & -0.209 & -0.138 & -0.300 & $-0.695 * *$ & 0.071 \\
\hline
\end{tabular}

Source: 2001/02 AYSP

${ }^{\mathrm{a}}$ Controlling for province, month of interview, day of week, standard errors corrected for clustering on PSUs.

n.a. $=$ not applicable

* Statistically significant at $10 \%$ level

** Statistically significant at 5\% level

*** Statistically significant at $1 \%$ level 
Because it is much easier to define a rural community than an urban one, we expected that our community variables would be more likely to show statistically significant associations with work time in rural areas. Although the community survey identified opportunities within a two-kilometer radius of each primary sampling unit, opportunities beyond two kilometers may still be accessible to urban residents, given the greater ease of transport. While we did find more associations in rural areas, we also found some relationships in urban areas. We found that the presence of a government source of water is significantly associated with a reduction of unpaid economic work time for males in urban areas and for females in rural areas. It is also significantly associated with a reduction in noneconomic household work time for males in rural areas (where there appears to be a gender division of labor, with males doing the outside domestic chores such as fetching water while females remain in the household).

The presence of a factory has a highly significant association with hours in paid work for both males and females in rural areas (Table 10), increasing paid work on average for males by two hours and for females by three hours. We see some compensating effects of a local factory in reducing noneconomic household work for young males and females, particularly young females (Table 14), and in reducing unpaid economic work for young females (Table 12).

The presence of a vocational institute for young males appears to be associated with increased paid work for males aged 20-24 in rural areas, which is compensated for by a significant reduction in time for noneconomic household work. On the other hand, the presence of a vocational institute for young rural females (these institutes are sexsegregated) appears to be significantly associated with increased time in unpaid economic work, suggesting that the skills being acquired by young females are more likely to prepare them for unpaid than for paid work. The presence of a vocational school also appears to be associated with an increase in unpaid economic work for young urban females.

The presence of schools in the community that go beyond the primary level are strongly associated with a reduction in paid work for young females. In urban areas, the association is greatest when secondary or higher secondary is the highest level available within two kilometers and is significant only for the younger age group, who may still be enrolled in school and therefore have few hours available for paid work. At older ages, the presence of a middle school appears to be associated with an increase in time in unpaid economic work. In rural areas, however, the associations, which are greatest when middle or secondary is the highest level available, are apparent for young females of all ages, even those who would have long since left school. This result is counterintuitive, as one might expect higher levels of schooling to prepare females for paid work. Just the opposite appears to be true, however. Females in the poorest families are the most likely to do paid work in rural areas; females in the richest families are likely to be able to pursue an education, find a good match in the marriage market, and relieve themselves of any obligation to earn money for the family.

To summarize, workloads for young males and females remain relatively equal as long as they remain in school. Upon school exit, males for the most part take up paid 
work outside the home, while females take up noneconomic household work, primarily of the sort that can be done within the home. Our results demonstrate that opportunities at the community level for higher levels of schooling, for vocational training, and for jobs (in the form of factories) are strongly associated with time-use patterns among young people, patterns that have implications for the timing of transitions to adulthood. Indeed, a recent rise in paid work for females suggests a possible response to changing employment opportunities. However, these growing opportunities do not seem to be altering certain strongly held norms against paid work for young females. For example, vocational training for females seems to be associated with an increase in unpaid economic work, whereas vocational training for males is associated with more time spent in paid work. Furthermore, the presence of higher-level schools for females seems to be associated with a decline in paid work and a rise in unpaid economic work.

\section{CONCLUSIONS}

Pakistan is a country of contrasts caught in the conflicting tensions between global political and economic change on the one hand and severe financial duress owing to a sluggish economy on the other. While the last couple of decades have brought much social and economic change, many aspects of daily life remain unchanged. As a result there are growing contradictions between traditional values and ways of life and increasingly accepted global norms and external economic realities. The circumstances under which today's young people are assuming adult roles will have long-term implications for their future prospects and for those of their families, their communities, and the country as a whole.

Our results confirm the fundamental importance of schooling to transitions to adulthood in Pakistan. Without schooling, children in Pakistan are asked to assume the work burdens of adults prematurely and are deprived of the opportunity for learning in an institutional setting outside the family. Those who attend school eventually assume gender-stereotyped roles; however, they do so with some delay, which allows them to experience a longer transition to adulthood. For both males and females, there appears to be a substantial lag in years between the assumption of adult work roles and assumption of adult family roles as marked by the timing of the transition to marriage. For young males this is a lag between the timing of first paid work and marriage; in the case of young females it is the lag between school exit or (if never in school) the assumption of heavy domestic responsibilities and the timing of marriage and leaving home. Our data demonstrate the potential for change created by higher levels of schooling, vocational training, or formal-sector jobs. As Pakistan's demographic transition continues (Feeney and Alam 2003; Sathar and Casterline 1998), family sizes become smaller, and women's time becomes more flexible, greater educational and labor force opportunities should become available for young women. 
NOTES

${ }^{1}$ For particular historical reasons in the United States, these results could be explained by changes in the timing of military service.

${ }^{2}$ For example, a series of marriage surveys conducted in four Asian countries in the late 1970s included retrospective data on the timing of key events in the transition; but because the respondents were restricted to married women and their husbands, the samples of younger women are highly selective. These data can provide baseline information on transitions to adulthood occurring during the 1950s and 1960s (e.g., Fricke et al. 1986 for Pakistan).

${ }^{3}$ It appears that enrollment rates calculated from the household survey are lower than rates calculated from the adolescent survey, even when comparisons are confined to those young people subsequently interviewed. This suggests that "knowledgeable" informants are not always as well informed as we assume.

${ }^{4}$ We do not include the timing of first birth in our analysis because it is so closely linked with first marriage; instead we consider the timing of first marriage as representing the transition to parenthood.

${ }^{5}$ All survey respondents contribute information to each year within the early phase of the transition. Information for the middle and late phases of the transition is more selective in that only those who have reached a particular age can contribute information to the life-table construction for that age.

${ }^{6}$ Because the incidence of first work varies over time, the assumptions of a proportional hazards model are violated. When this time variance is controlled for in a Poisson regression, there is a significant difference between the two female age cohorts, such that the incidence rate ratio of the older to the younger cohort is $0.839(\mathrm{P}=0.030)$ for those who never attended school and $0.767(\mathrm{P}=0.004)$ for those who ever attended school.

${ }^{7}$ For transitions before the age of 15, data from the life-event calendar for all respondents were included in the calculation. For transitions before age 20, life-event calendar data were included for the 20-24 age group, all of whom had reached the age of 20. Finally, for transitions before age 24, only the experience of those aged 24 could be included.

${ }^{8} \mathrm{~A}$ joint transition occurs when two events are reported within the same time interval.

${ }^{9}$ Age groups are 15-16, 17-19, 20-21, and 22-24. Because there is considerable age heaping at age 18, some who report themselves as 18 may in fact be younger or older. Because 18 is the legal age of majority in Pakistan, there may be some incentive for those who have assumed adult roles to report themselves as 18 .

${ }^{10}$ In comparing the AYSP data on daily time spent in noneconomic household work for young females (15-19) with time-use data on housework collected from female household members in the 1991 Pakistan Integrated Household Survey (PIHS), we find significantly greater time reported on domestic chores in the AYSP. Mean weekly hours for those reporting housework was 27 from the PIHS and 44 in AYSP (by converting daily hours to weekly hours). We suspect this was because of the different reporting techniques; in PIHS, females were asked how many times in the past seven days they performed 12 different household activities and, for each, how much time they spent; in 
the AYSP, respondents were asked to recall their activities in the previous 24-hour period. While in the AYSP all adolescents responded directly about their own activities, in the PIHS only 53 percent responded about their own activities, with slightly more time reported by self-reporters than when others responded on the adolescent girl's behalf (Durrant 2003; Sathar et al. 2003).

${ }^{11}$ This observation is based on the time-use data of hours in school by current class attended.

12 Although 8,069 respondents completed the survey, only 7,923 completed the entire time-use profile. Therefore, Tables 5-14 are restricted to this subset of respondents.

13 Additional variables included but not shown are dummies for province, month of interview, and day of the week for which time use was reported. Other household variables that were tried and found not to be significant included whether or not the young person was a relative of the head and whether or not the household was femaleheaded. We did not include a variable representing whether or not the household was the young person's natal home. For females, this is synonymous with whether or not they are married-a status which we consider endogenous to intrahousehold decisionmaking about resource allocation and time use within the household.

${ }^{14}$ We can see from Table 8 that the distribution of household socioeconomic status differs widely between rural and urban areas. This is not surprising but raises questions about whether it might have been more appropriate to create specific urban and rural measures that could effectively differentiate between socioeconomic groups within each residential category separately.

${ }^{15}$ We had wanted to include some variables representing local wages rates for men and women. While these questions were asked in the community survey, many communities were not able to report a local wage for women; and, while most reported a local wage for unskilled men, there was very little variation in reported wages across communities. An alternative not yet pursued would be to use wages for those currently working to construct estimates at the community level.

${ }^{16}$ The community module of the questionnaire asked knowledgeable informants about the presence of various levels of schooling within the community. Unfortunately they were not asked whether a particular level of school also encompassed lower levels within it; such schools are called composite schools. Given the evidence from earlier research that the presence of a school of a higher level within a community (Lavy 1996) encourages enrollment at lower levels because there is a greater chance that students can move on, it seemed plausible to assume that higher levels of schooling would encourage enrollment in that level and in lower levels.

17 In a household decisionmaking model of the determinants of child outcomes, household composition variables can be seen as endogenous when parents are the prime decisionmakers. However, we are modeling the behavior of young people who are in a transition to adulthood. If we assume that young people have growing agency in their decisionmaking about work roles relative to their parents, it is not unreasonable to see household composition variables as exogenous, rather than endogenous. 


\section{REFERENCES}

Ajayi, A., W. Clark, A. Erulkar, K. Hyde, C.B. Lloyd, B.S. Mensch, C. Ndeti, B. Ravitch, E. Masiga, and S. Gichaga

1997 Schooling and the Experience of Adolescents in Kenya. New York and Nairobi, Kenya: Population Council and Government of Kenya Ministry of Education.

Arends-Kuenning, M. and S. Amin 2004 "School initiative programs and children's activities: The case of Bangladesh" Comparative Education Review, forthcoming.

Bollen, Kenneth A., Jennifer L. Glanville, and Guy Stecklov.

2002 "Economic status proxies in studies of fertility in developing countries: Does the measure matter?" Population Studies, 56(1): 81-96.

Brown, L.R., and L. Haddad

1995 Time Allocation Patterns and Time Burdens: A Gendered Analysis of Seven Countries. Washington, DC: International Food Policy Research Institute.

Durrant, V.L.

2000 Adolescent girls and boys in Pakistan: Opportunities and constraints in the transition to adulthood. Research Report No. 12. Islamabad: Population Council.

2003 Personal communication.

Echarri Canovas, C.J., and J. Perez Amador

2001 Becoming adults: Life course transitions in Mexican young people. Paper presented at International Union for the Scientific Study of the Population XXIV General Population Conference, Salvador-Brazil, IUSSP.

Federal Bureau of Statistics

1998 PIHS education sector performance in the 1990s: Analysis from the PIHS. Pakistan Integrated Household Survey. Islamabad: Government of Pakistan.

Feeney, G. and I. Alam

2003. "New estimates and projections of population growth in Pakistan." Population and Development Review 29(3): 483-492.

Filgueira, C., F. Filgueira, and A. Fuentes 2001 Critical choices at a critical age: Youth emancipation paths and school attainment in Latin America. Latin American Research Network Working Paper $\# R-432$, Inter-American Development Bank. 
Filmer, D., and L. Pritchett

1999 The effect of household wealth on educational attainment: Evidence from 35 countries. Population and Development Review 25(1):85-120.

Florez, C.E., and D.P. Hogan

1990 Demographic transition and life course change in Colombia. Journal of Family History 15(1):1-21.

Fricke, T.E., S.H. Syed, and P.C. Smith

1986 Rural Punjabi social organization and marriage timing strategies in Pakistan. Demography 23(4):489-508.

International Planned Parenthood Federation, and International Women's Rights Action Watch

2000 Reproductive Rights 2000. London: Terracotta Press. Available: http://www.ippf.org.

Larson, R.W., and S. Verma

1999 How children and adolescents spend time across the world: Work, play, and developmental opportunities. Psychological Bulletin 125(6 ):701-736.

Lavy, V.

1992 Investment in Human Capital, School Supply Constraints in Rural Ghana. Living Standards Measurement Study Working Paper Number 93. Washington, DC: The World Bank.

1996 School supply constraints and children's educational outcomes in rural Ghana. Journal of Development Economics 51:291-314.

Levison, D., and K.S. Moe

1998 Household work as a deterrent to schooling: An analysis of adolescent girls in Peru. Journal of Developing Areas 32(3):339-356.

Levison, D., K.S. Moe, and F.M. Knaul

2001 Youth education and work in Mexico. World Development 29(1):167188.

Mensch, B.S., J. Bruce, and M.E. Greene

1998 The Uncharted Passage: Girls' Adolescence in the Developing World. New York: Population Council.

Mensch, B.S., S. Singh, and J. Casterline 2003 Trends in the Timing of First Marriage among Men and Women in the Developing World. Paper prepared for the annual meeting of the Population Association of America, Minneapolis, May 1-3.

Rindfuss, R.R.

1991 The young adult years: Diversity, structural change, and fertility. 
Demography 28(4):493-512.

Sathar, Z.A., and J.B. Casterline

1998. "The onset of fertility transition in Pakistan." Population and Development Review 24(4): 773-796.

Sathar, Z.A., C.B. Lloyd, M. ul Haque, J.A. Diers, A. Faizunnissa, M. Grant, and M. Sultana

2003 Adolescents and Youth in Pakistan 2001-02: A Nationally Representative Survey. Islamabad: Population Council.

United Nations General Assembly

1990 Convention on the Rights of the Child.

Available: http://www.unicef.org/crc/fulltext.htm.

Winsborough, H.H.

1978 Statistical histories of the life cycle of birth cohorts: The transition from schoolboy to adult male. Pp. 231-259 in Social Demography. New York: Academic Press.

Xenos, $\mathrm{P}$.

1999 Events information and the life course framework in young adult reproductive health (YARH) survey studies of adolescent risk. Paper prepared for the YARH Measurement Meeting, Focus on Youth, Centers for Disease Control, Decatur, Georgia. 


\section{POLICY DIVISION WORKING PAPERS}

If still in print, single copies of up to three working papers from 1989 through 2003 are available free of charge.

Beginning with the 2004 issues, the working papers will no longer be available in print format. Instead they will be distributed electronically. As each new paper is completed subscribers will be notified by e-mail and a link to the paper will be provided.

To subscribe to the Policy Research Division working paper e-mail notification list, or to obtain back issues from 1989 to 2003, please send your request to prdwp@popcouncil.org.

PDFs of recent issues are available at www.popcouncil.org/publications/wp/prd/rdwplist.html

2004

188 Cynthia B. Lloyd and Monica J. Grant, "Growing up in Pakistan: The separate experiences of males and females."

187 Zachary Zimmer, Xianghua Fang, Toshiko Kaneda, Zhe Tang, and Julia Kwong. "Trends and transitions in children's coresidence with older adults in Beijing municipality."

186 Sajeda Amin and Alaka M. Basu. "Popular perceptions of emerging influences on mortality and longevity in Bangladesh and West Bengal."

185 John Bongaarts. "Population aging and the rising cost of public pensions."

184 Mark R. Montgomery and Paul C. Hewett. "Urban poverty and health in developing countries: Household and neighborhood effects.
2003

183 Agnes R. Quisumbing and Kelly Hallman. "Marriage in transition: Evidence on age, education, and assets from six developing countries."

182 Paul C. Hewett, Barbara S. Mensch, and Annabel S. Erulkar, "Consistency in the reporting of sexual behavior among adolescent girls in Kenya: A comparison of interviewing methods."

181 Zachary Zimmer, Linda G. Martin, and Hui-Sheng Lin, "Determinants of old-age mortality in Taiwan."

180 Frank K. Nyonator, J. Koku Awoonor-Williams, James F. Phillips, Tanya C. Jones, and Robert A. Miller, "The Ghana Community-based Health Planning and Services Initiative: Fostering evidence-based organizational change and development in a resourceconstrained setting."

179 John Bongaarts and Griffith Feeney, "Estimating mean lifetime."

\footnotetext{
* No longer available as a printed publication. Download electronic file from Web site only.
} 
178 Elizabeth F. Jackson, Patricia Akweongo, Evelyn Sakeah, Abraham Hodgson, Rofina Asuru, and James F. Phillips, "Women's denial of having experienced female genital cutting in northern Ghana: Explanatory factors and consequences for analysis of survey data."

177 John Bongaarts, "Completing the fertility transition in the developing world: The role of educational differences and fertility preferences."

176 Cynthia B. Lloyd and Paul C. Hewett, "Primary schooling in sub-Saharan Africa: Recent trends and current challenges."

175 James F. Phillips, Tanya C. Jones, Frank K. Nyonator, and Shruti Ravikumar, "Evidence-based development of health and family planning programs in Bangladesh and Ghana."

174 Geoffrey McNicoll, "Population and development: An introductory view."

173 Paul Demeny, "Population policy: A concise summary."

172 Zachary Zimmer, Napaporn Chayovan, Hui-Sheng Lin, and Josefina Natividad, "How indicators of socioeconomic status relate to physical functioning of older adults in three Asian societies."

171 Sajeda Amin and Nagah H. AlBassusi, "Wage work and marriage: Perspectives of Egyptian working women."
170 Ravai Marindo, Steve Pearson, and John B. Casterline, "Condom use and abstinence among unmarried young people in Zimbabwe: Which strategy, whose agenda?"

169 Zachary Zimmer and Julia Dayton, "The living arrangements of older adults in sub-Saharan Africa in a time of HIV/AIDS."

168 Paul C. Hewett, Annabel S. Erulkar, and Barbara S. Mensch, "The feasibility of computerassisted survey interviewing in Africa: Experience from two rural districts in Kenya."

2002

167* Dominic K. Agyeman and John B. Casterline, "Social organization and reproductive behavior in southern Ghana."

166* Carol E. Kaufman and Stavros E. Stavrou, “'Bus fare, please': The economics of sex and gifts among adolescents in urban South Africa."

165 Kelly Hallman, Agnes R. Quisumbing, Marie Ruel, and Bénédicte de la Brière, 'Childcare, mothers' work, and earnings: Findings from the urban slums of Guatemala City."

164 Cynthia B. Lloyd, Cem Mete, and Zeba A. Sathar, "The effect of gender differences in primary school access, type, and quality on the decision to enroll in rural Pakistan."

\footnotetext{
* No longer available as a printed publication. Download electronic file from Web site only.
} 
163 Barbara S. Mensch, Wesley H. Clark, and Dang Nguyen Anh, "Premarital sex in Vietnam: Is the current concern with adolescent reproductive health warranted?"

162 Naomi Rutenberg, Carol E. Kaufman, Kate Macintyre, Lisanne Brown, and Ali Karim, "Pregnant or positive: Adolescent childbearing and HIV risk in South Africa."

161 John Bongaarts, "The end of the fertility transition in the developing world."

160* Julia Dayton and Martha Ainsworth, "The elderly and AIDS: Coping strategies and health consequences in rural Tanzania."

159 Carol E. Kaufman, Shelley Clark, Ntsiki Manzini, and Julian May, "How community structures of time and opportunity shape adolescent sexual behavior in South Africa."
158 Geoffrey McNicoll, "Demographic factors in East Asian regional integration."

157 Zachary Zimmer and Sovan Kiry Kim, "Living arrangements and socio-demographic conditions of older adults in Cambodia."

156 John Bongaarts and Griffith Feeney, "How long do we live?"

155 Zachary Zimmer, Linda G. Martin, and Ming-Cheng Chang, "Changes in functional limitations and survival among the elderly in Taiwan: 1993, 1996, and 1999."

* No longer available as a printed publication. Download electronic file from Web site only. 